Article

\title{
Thermal Performance Combined with Cooling System Parameters Study for a Roller Kiln Based on Energy-Exergy Analysis
}

\author{
Yali Wang, Haidong Yang * and Kangkang Xu
}

School of Electromechanical Engineering, Guangdong University of Technology, Guangzhou 510006, China; yayaw0603@163.com (Y.W.); xukangkang@gdut.edu.cn (K.X.)

* Correspondence: yanghd@gdut.edu.cn

Received: 6 July 2020; Accepted: 29 July 2020; Published: 31 July 2020

\begin{abstract}
Roller kilns, characterized as high energy consumption equipment, are widely used in the firing process of ceramic tiles. To evaluate the thermal performance of a roller kiln, a detailed energy and exergy analysis is carried out employing the operating values from a typical ceramic factory. In this study, parametric studies are performed that examine the impacts of the roller kiln's cooling system on thermal performance, fuel-saving, cost-saving, and environmental influence. The results show that the targeted energy only accounts for $13.4 \%$ and $9.7 \%$ of the total energy and exergy inputs, indicating the poor efficiency of the roller kiln. This research also identifies that the exergy destruction is the largest cause of the exergy loss in the system, accounting for $85.1 \%$ of the total exergy input—of which $50.9 \%$ is due to heat and mass transfer, and $37.9 \%$ is caused by fuel combustion. Based on the parametric studies, it has been found that with every $1 \%$ increase in cooling air mass flow, the energy and the exergy efficiencies of the kiln increase by $0.06 \%$ and $0.04 \%$; with every $1 \%$ increase in cooling gas temperature, the energy and the exergy efficiencies of the kiln drop by $0.09 \%$ and $0.07 \%$; with every $1 \%$ increase in cooling gas residence time, the energy and the exergy efficiencies of the kiln increase by $0.16 \%$ and $0.12 \%$. Furthermore, results show that the cooling air residence time has the main impact on the cost-saving and carbon dioxide emission reduction, followed by cooling air mass and cooling air temperature.
\end{abstract}

Keywords: ceramic roller kiln; energy analysis; exergy analysis; parametric study; irreversibility

\section{Introduction}

Roller kilns are typical equipment used in the wall and floor tile manufacturing. The firing process occurring in roller kilns is the greatest energy consumption stage, accounting for $55 \%$ of the total thermal energy in tile production [1]. Therefore, various studies have been carried out on the energy analyses for the kiln [2-5]. Massimo Milani et al. [2] employed a new heat-recovery burner for the internal heat recovery in a ceramic kiln. Based on the lumped and distributed parameter model, the results showed that $10 \%$ of the fuel can be saved. Bertrand Delpech et al. [3] carried out research on the heat recovery by the application of heat-pipe for the ceramic kiln, which reduced the natural gas by $110,600 \mathrm{Sm}^{3}$ per year. Hasan Caglayan et al. [4] used the cooling gas with a temperature of $148^{\circ} \mathrm{C}$ instead of the ambient air for the firing process-the results showed the natural gas could be reduced by $10 \%$. Ana Mezquita et al. [5] recovered the cooling gas into the kiln's firing chamber, and the percentage of energy saved could be up to $17 \%$, based on their calculation methodology. Whereas, most of the previous studies focus on the energy conservation for the kiln, and the literature refers to the investigation of energy quantification and quality, and the identification of the key factors affecting thermal efficiency for the kiln are limited. 
Exergy analysis is a powerful tool in the thermodynamic evaluation of complex engineering processes that not only consider the energy quantity, but also energy quality, and its degradation and irreversibility. In recent years, exergy analysis has been widely applied to evaluate the thermal performance of the energy-related systems for various industrial sectors [6]. There are many exergy studies for the cement industry [7-13]. C. Koroneos et al. [7] performed an exergy assessment for the cement production, and concluded that raw feed preheating, clinker cooling and combustion were the greatest losses of exergy. Zafer Utlu et al. [8] evaluated thermodynamic utilization efficiencies for a raw cement mill, and pointed out that this technique was a powerful tool in the analysis and establishment of energy-saving policies. Ehsan Amiri Rad et al. [9] also carried out energy and exergy analysis for the pressure optimization of a waste heat recovery boiler in a cement plant. Based on the exergy analysis, M. Ziya SÖĞÜT [10] calculated the potential of $\mathrm{CO}_{2}$ emissions, due to exergetic losses of the coal mixture, natural gas and fuel-oil for a Turkish cement sector. S. Karellas et al. [11] used exergy analysis as a method to compare the efficiency of two different waste heat recovery approaches. Regarding clinker production, Maria Luiza Grillo Renóet al. [12] confirmed the advantage of waste spent pot lining as a mineralizer from an exergetic perspective. Abid Ustaoglu et al. [13] also carried out the energy and exergy analyses to assess exergy loss and destruction for a wet type rotary kiln. For the iron and steel industry, U. Camdali et al. [14] calculated irreversibility and exergy efficiency for a ladle furnace using the second law of thermodynamics. According to the exergy analysis, Mehmet Selçuk Mert et al. [15] identified the most efficient component and inefficient components in a cogeneration plant for an iron and steel factory. Junnian Wu et al. [16] carried out a comprehensive estimate of energy and $\mathrm{CO}_{2}$ emissions using exergy to explore the impact on the environment of an iron and steel industrial network. W. Rong et al. [17] also identified the main factors affecting exergy efficiency by using exergy analysis for a rotary kiln-electric furnace. Regarding a lime production plant, according to the first and second laws of thermodynamics, Wenjie Rong et al. [18] determined the energy and exergy efficiencies for an annular shaft kiln, and revealed the dominant factor affecting the exergy efficiency. Alexis Sagastume Gutiérrez et al. [19] also investigated energy and exergy performance to identify the main factors causing exergy destruction for a lime shaft kiln. Moreover, exergy analysis has also been used in the plaster and magnesium productions. Mert Gürtürk et al. [20,21] made a detailed energy and exergy analysis for a plaster rotary kiln and proposed measures to improve exergy efficiency. Vladan Karamarkovic et al. [22] identified the kiln shell and exhaust gases as the major reasons for heat loss in a magnesium production company using energy and exergy analyses. Numerous studies have shown that exergy analysis is a powerful tool that can provide a better investigation of thermal performance and efficiency improvement for energy-related systems.

Although the previous research has been performed to evaluate the thermal efficiency for various industrial facilities from the exergetic perspective, there is very limited literature regarding the exergy analysis for the ceramic industry. Zafer Utlu et al. [23] used energetic and exergetic analysis methods to evaluate the performance of the drying system in a ceramic plant. Canan Kandilli et al. [24] also adopted the exergy method to optimize the hydrogen mass flow rate for the ceramic enrichment application. Hasan Caglayan et al. [25] applied exergy analysis to analyze the cogeneration system in the ceramic industry. Their research mainly focused on drying equipment, oxygen-rich kiln and cogeneration system for the ceramic industry. Regarding roller kilns, only one paper [26] performed the exergy analysis on this equipment. However, the sources of exergy destruction are not discussed in detail in their exergy analysis. Indeed, the further classification of exergy destruction is beneficial to identify the evitable and inevitable exergy destruction and the evitable exergy loss for the roller kiln, which could help in the accurate verdict of energy conservation potential. Furthermore, previous studies mainly focus on the heat recovery from the cooling system, and the parametric studies of the cooling system are not reported in the literature.

Therefore, the purpose of the present paper is to evaluate the thermal performance, based on a comprehensive energy and exergy analysis, and investigates the exergy destruction for the actual roller kiln. Furthermore, the influences of cooling system parameter on thermal performance, fuel-saving, 
cost-saving and environmental impact are discussed. The present research's focuses are described as follows:

- To analyze and quantify the energy and exergy of each stream based on energy-exergy analysis model, and identify key factors affecting the thermal efficiency of the process.

- To analyze and quantify the main sources of energy and exergy loss, and identify the evitable and inevitable exergy destruction and the evitable exergy loss for the roller kiln.

- To carry out the parametric studies of the cooling system for investigating the influence on thermal performance, fuel-saving, cost-saving and environmental impact for the roller kiln.

\section{Description of the Roller Kiln}

The studied roller kiln, located in a ceramic factory in Foshan, China, is used in the firing process to produce polished tiles with a production of about $8711 \mathrm{~kg} / \mathrm{h}$. It is a single-deck kiln with a length of $310 \mathrm{~m}$, including 155 modules, each of which is $2 \mathrm{~m}$ long. Tiles are placed on the plane formed by the arranged in-parallel rollers, and then conveyed by the rotary rollers to travel through the roller kiln for firing.

The roller kiln consists of a heating system and a cooling system. The heating system, which is divided into a preheating phase (environment temperature to $600 \mathrm{~K}$ ) and a firing phase ( $600 \mathrm{~K}$ to firing temperature) according to the different temperature values. In the preheating phase, there is no burner, and the required heating comes from the hot flue gas of the firing process. The residual water and adsorptive water in the unfired tile are eliminated in this process. The firing phase, which is the most important process in the roller kiln, involves structural water removal, chemical reactions and crystal transformation of the ceramic tile. In the real case, 200 burners are installed to supply the heat required by physical-chemical reactions. The firing temperature of this system is about $1413 \mathrm{~K}$, which is mainly affected by the openings of the burner. The cooling system follows the heating system. In the cooling system, a fired tile usually experiences a rapid cooling and slow cooling process to form a high density, and good crystal fired tile. The cooling of the tile from $1413 \mathrm{~K}$ to $392 \mathrm{~K}$ can be achieved by injecting ambient air with different rates at different kiln locations. Note that the fast transformation of the crystalline form occurs at $846 \mathrm{~K}$, accompanied by volume contraction, so the slow cooling is required within the range of the temperature to avoid cracks. In the cooling process, the ambient air absorbs the heat from the high-temperature tile, and then forms the cooling gas. Some of the hot pollution-free gas can be directly extracted from the firing zone as oxidizing air or used for other plant facilities, such as the dryer. Another part cooling gas with lower temperature is directly released into the atmosphere in the current case.

The firewall is installed at the interface of the heating system and cooling system, which not only avoids the backflow of the flue gas from the firing section, but also decreases the transverse temperature difference, due to rapid cooling airflow to the firing zone when the pressure fluctuates.

The roller kiln is characterized by the opposite movement of the tile and hot air. The unfired tile enters at the kiln head, then travels through the heating system and cooling system at a constant speed, and finally becomes the fired tile, which is discharged from the kiln tail.

Figure 1 schematically shows the studied kiln.

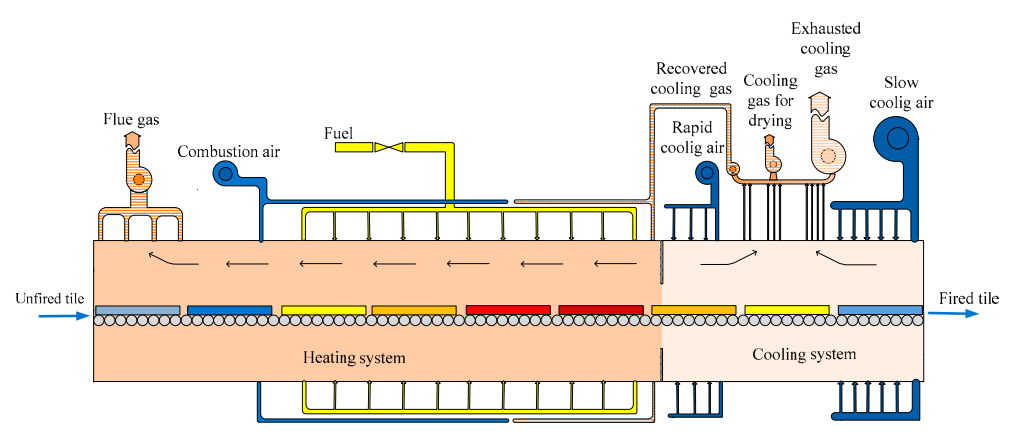

Figure 1. Schematic diagram of the roller kiln. 


\section{Theoretical Analysis}

Energy analysis, based on the first law of thermodynamics, is a traditional method for thermal performance analysis that can quantify the conversion, utilization and loss of energy in quantity. Nevertheless, it cannot identify or quantify of the true scale, degradation and irreversibility of the energy. In this paper, the first and second laws of thermodynamics are combined to comprehensively discuss the thermal performance of the roller kiln.

For the studied kiln, the evaluation of thermal performance is based on the following assumptions: (1) The roller kiln is assumed to be an open system running under a steady state; (2) the kinetic and potential energy changes are neglected in the analysis; (3) the gases in the process are assumed to be ideal gases; (4) the electrical energy used in the process is not considered; (5) for the environment, the temperature and pressure are assumed to be $\mathrm{T}_{0}=298 \mathrm{~K}, \mathrm{P}_{0}=1 \mathrm{~atm}$.

\subsection{Mass and energy balances}

The general equation for mass balance is expressed as:

$$
\sum_{i} \dot{m}_{i n, i}=\sum_{j} \dot{m}_{\text {out }, j}
$$

where $\dot{m}_{\text {in }}$ stands for the mass flow of the inlet and $\dot{m}_{\text {out }}$ stands for the mass flow of the outlet.

The energy balance can be defined as:

$$
\sum_{i} \dot{E n_{i n, i}}=\sum_{j} \dot{E n_{o u t}, j}
$$

where $\dot{E} n_{\text {in }}$ is the energy input flow and $\dot{E n_{\text {out }}}$ is the energy output flow. Table 1 summarizes some equations used in energy analysis [18,27].

Table 1. Equations used in energy analysis.

\begin{tabular}{ccc}
\hline Term & Equation & Explanation \\
\hline General calculation equation & $E n=c_{p} \cdot m \cdot \Delta T(1)$ & where $c_{p}$ is the specific heat, and $T$ is the temperature. \\
Combustion heat of the fuel & $E n_{f}=m \cdot L H V(2)$ & where $L H V$ is low heating value of the fuel. \\
Latent heat & $E n_{w a}=m \cdot r(3)$ & where $r$ is latent heat of vaporization. \\
Chemical reaction & $E n_{c h}=m \cdot q(4)$ & where $q$ is the reaction heat. \\
Kiln wall heat loss & $E n_{k w}$ & (pls. see Equations (3) and (4) and equations in Table 2 \\
\hline
\end{tabular}

The heat transfer through the system to the environment consists of three processes: The high-temperature fluid and the system's inner surface, the wall, and the system's outer surface and the environment. Heat transfer of the system occurs in three different ways: Conduction, convection and radiation. Heat transfer in the system is considered to be a stable process. The diagram of the heat transfer process is shown in Figure 2.

Energy loss between the control system and environment can be evaluated as [28]:

$$
E n_{k w}=\frac{T_{i n}-T_{o u t}}{R_{T}} \times A
$$

where $A$ is the heat dissipation area and $R_{T}$ means the total thermal resistance, which can be expressed as:

$$
R_{T}=R_{\text {in }}+R_{\text {wall }}+R_{\text {out }}
$$

Here, $R_{\text {in }}, R_{\text {wall }}$ and $R_{\text {out }}$ can be determined by equations in Table 2, respectively. The equations are summarized in Table 2. 


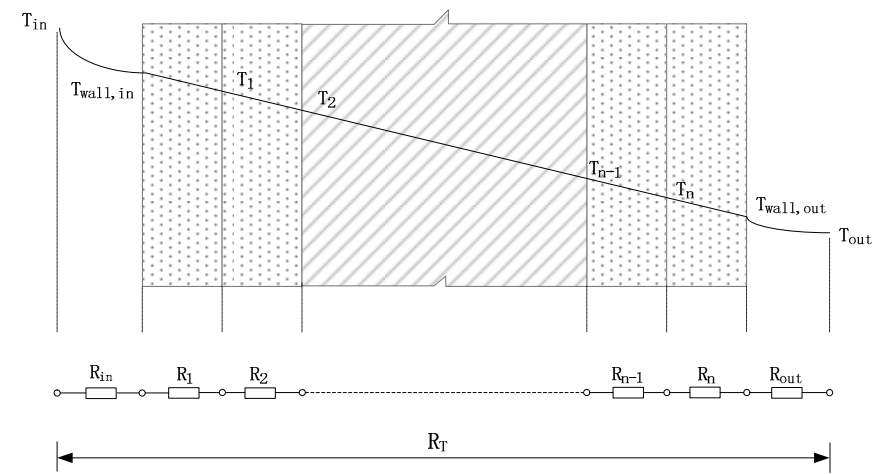

Figure 2. The thermal resistance of heat transfer through the kiln to the atmosphere.

Table 2. Thermal resistance equations [28,29].

\begin{tabular}{cc}
\hline Equation & Explaination \\
\hline$R_{i n}=\frac{1}{a}(1)$ & $\begin{array}{c}\text { where } a \text { is convection coefficient. } \\
R_{\text {wall }}=R_{1}+R_{2}+\ldots+R_{n-1}+R_{n}=\sum \frac{\delta_{i}}{\lambda_{i}}(2)\end{array}$ \\
$R_{\text {out }}=\frac{1}{h\left(T_{w o}-T_{0}\right)^{0.25}}+\frac{1}{\varepsilon \sigma\left(T_{w 0}^{2}+T_{0}^{2}\right) \cdot\left(T_{w o}+T_{0}\right)}(3)$ & $\begin{array}{c}\text { where } \delta_{i} \text { and } \lambda_{i} \text { are the thickness and conductivity coefficient of } \\
\text { material layer of } i, \text { respectively. } \\
\text { where } h \text { is position coefficient, } \varepsilon \text { is the emissivity of the surface, } \\
\text { and } \sigma \text { is Stefane-Boltzman constant as } 5.67 \times 10^{-8} \mathrm{~W} / \mathrm{m}^{2} \mathrm{~K}^{4} .\end{array}$ \\
\hline
\end{tabular}

Energy efficiency is a significant parameter for assessing thermal performance. Its definitions depend on different research purposes [17]. In this case, the energy efficiency of the kiln can be defined as the ratio of physical-chemical reaction energy to the input energy, which is expressed as:

$$
\eta_{e n}=\frac{\sum \dot{E} n_{\text {reac }}}{\sum \dot{E} n_{\text {in }}}
$$

\subsection{Exergy Balance}

The general form of exergy balance is given by:

$$
\sum_{i} \dot{E} x_{i n, i}=\sum_{j} \dot{E} x_{o u t, j}+\dot{E} x_{D}
$$

where $\dot{E} x_{i n}, \dot{E} x_{o u t}$ and $\dot{E} x_{D}$ denote the exergy input, exergy output and the exergy destruction, respectively. The exergy content of a flow is given by [20]:

$$
\dot{E x}=\dot{E} x_{p h}+\dot{E} x_{c h}
$$

where $\dot{E} x_{p h}$ and $\dot{E} x_{c h}$ are the physical and chemical exergy, respectively. Table 3 lists some equations used in exergy analysis [27,30,31].

Physical exergy is defined as the work obtainable by taking the matter through the reversible process from its initial state $(T, P)$ to the environmental state $\left(T_{0}, P_{0}\right)$, which can be expressed using Equation (1) in Table 3. Based on the first law of thermodynamics, the enthalpy change is estimated as follows:

$$
H-H_{0}=m \cdot c_{p} \cdot\left(T-T_{0}\right)
$$

The entropy change, based on the first and second laws of thermodynamics, is calculated as:

$$
S-S_{0}=m \cdot\left[c_{p} \cdot \ln \left(\frac{T}{T_{0}}\right)-R \cdot \ln \left(\frac{P}{P_{0}}\right)\right]
$$


Table 3. Equations used in exergy analysis.

\begin{tabular}{|c|c|c|}
\hline Term & Equation & Explanation \\
\hline General calculation equation of physical exergy & $E x_{p h}=H-H_{0}-T_{0}\left(S-S_{0}\right)(1)$ & $\begin{array}{c}\text { where } H \text { is the enthalpy and } S \text { is the entropy, the subscript } 0 \text { stands for the } \\
\text { ambient environment. }\end{array}$ \\
\hline Exergy of chemical reaction & $E x_{c r}=-m \cdot\left(G_{p}-G_{r}\right)(2)$ & where $G_{p}$ and $G_{r}$ are the Gibbs sum of products and reactants. \\
\hline Combustion exergy of the fuel & $E x_{\text {com }}=m \cdot \phi \cdot L H V(3)$ & where $\phi$ is the relation between the chemical exergy and $L H V$. \\
\hline Chemical exergy of a gas mixture & $E x_{g m}=m \cdot\left(\sum_{k} x_{k} e x_{c h, k}+R T_{0} \sum_{k} x_{k} \ln x_{k}\right)$ & $\begin{array}{c}\text { where } x \text { is the Molar fraction, } e x \text { is the specific exergy and } R \text { is the } \\
\text { universal gas constant. }\end{array}$ \\
\hline Latent heat of exergy & $E x_{l h}=m \cdot\left(1-\frac{T_{0}}{T_{p t}}\right) \cdot r(5)$ & where $T_{p t}$ is the phase-transition temperature. \\
\hline Kiln wall exergy loss & $E x_{k w}=\left(1-\frac{T_{0}}{T_{i n}}\right) \cdot Q(6)$ & $\begin{array}{c}\text { where } Q \text { is the amount of exchanged heat through the kiln wall, } T_{\text {in }} \text { is the } \\
\text { average temperature in the kiln. }\end{array}$ \\
\hline Exergy destruction & $E x_{D}=T_{0} \cdot S_{g e n}(7)$ & where $S_{g e n}$ represents for the entropy generation. \\
\hline
\end{tabular}


The pressure term on the right side is applicable to determine the entropy of the gas, but not of the liquid and the solid [27].

The chemical reaction, combustion exergy of the fuel, chemical exergy of the gas mixture, latent heat of exergy and kiln wall exergy loss can be evaluated using equations in Table 3, respectively. The exergy destruction is calculated using Equation (7) (Table 3) [27]. Similar to energy efficiency, the exergy efficiency is defined as follows:

$$
\eta_{e x}=\frac{\sum \dot{E} x_{\text {reac }}}{\sum \dot{E} x_{i n}}
$$

\subsection{Cost and Environmental Analysis}

System efficiency could be improved by involving a parameter analysis for working conditions optimization, which will lead to potential energy-saving and environmental emission reduction.

The amount of cost-saving can be calculated as follows:

$$
C S=E S \times E C
$$

where $E S$ and $E C$ are the energy-saving and energy cost, respectively.

The amount of environmental emission reduction is estimated as follows:

$$
E E R=F S \times F E
$$

where $F S$ and $F E$ are fuel-saving and emission per $\mathrm{kg}$ of fuel, respectively.

\subsection{Uncertainty Analysis}

There are errors existing in the measurements and calculated values, due to the uncertainty of experimental data collection. In the present research, the uncertainties associated with the measuring instruments are listed in Table 4. Uncertainty analysis is carried out by employing the approach explained in Refs. [32,33], which can be calculated by:

$$
\Delta y=\left[\left(\frac{\partial y}{\partial x_{1}} \Delta x_{1}\right)^{2}+\left(\frac{\partial y}{\partial x_{2}} \Delta x_{2}\right)^{2}+\ldots+\left(\frac{\partial y}{\partial x_{n}} \Delta x_{n}\right)^{2}\right]^{1 / 2}
$$

The relative uncertainty of the determined quantity is expressed as:

$$
\delta_{y}=\frac{\Delta y}{y} \cdot 100 \%
$$

Based on the Equations (13) and (14), the uncertainty value of energy and exergy efficiencies errors are determined as $7.30 \%$ and $8.19 \%$, respectively.

Table 4. The accuracy of the measuring instrument.

\begin{tabular}{cc}
\hline Instrument & Accuracy \\
\hline Weighing machine, $(\mathrm{kg})$ & $\pm 2 \%$ \\
Gas velocity measuring device, $(\mathrm{m} / \mathrm{s})$ & $\pm 2 \%$ \\
Thermocouple, $\left({ }^{\circ} \mathrm{C}\right)$ & $\pm 1.5 \%$ \\
Pressure Transducer, $(\mathrm{kPa})$ & \pm 3.0 \\
\hline
\end{tabular}

\section{Results and Discussion}

The studied kiln produces ceramic tiles with the dimensions of $600 \times 600 \mathrm{~mm}$ and if there is no interruption, usually works $24 \mathrm{~h}$ a day for several months. The operational data were obtained from a ceramics kiln. The mass, energy and exergy flows of the roller kiln are depicted in Figure 3. 


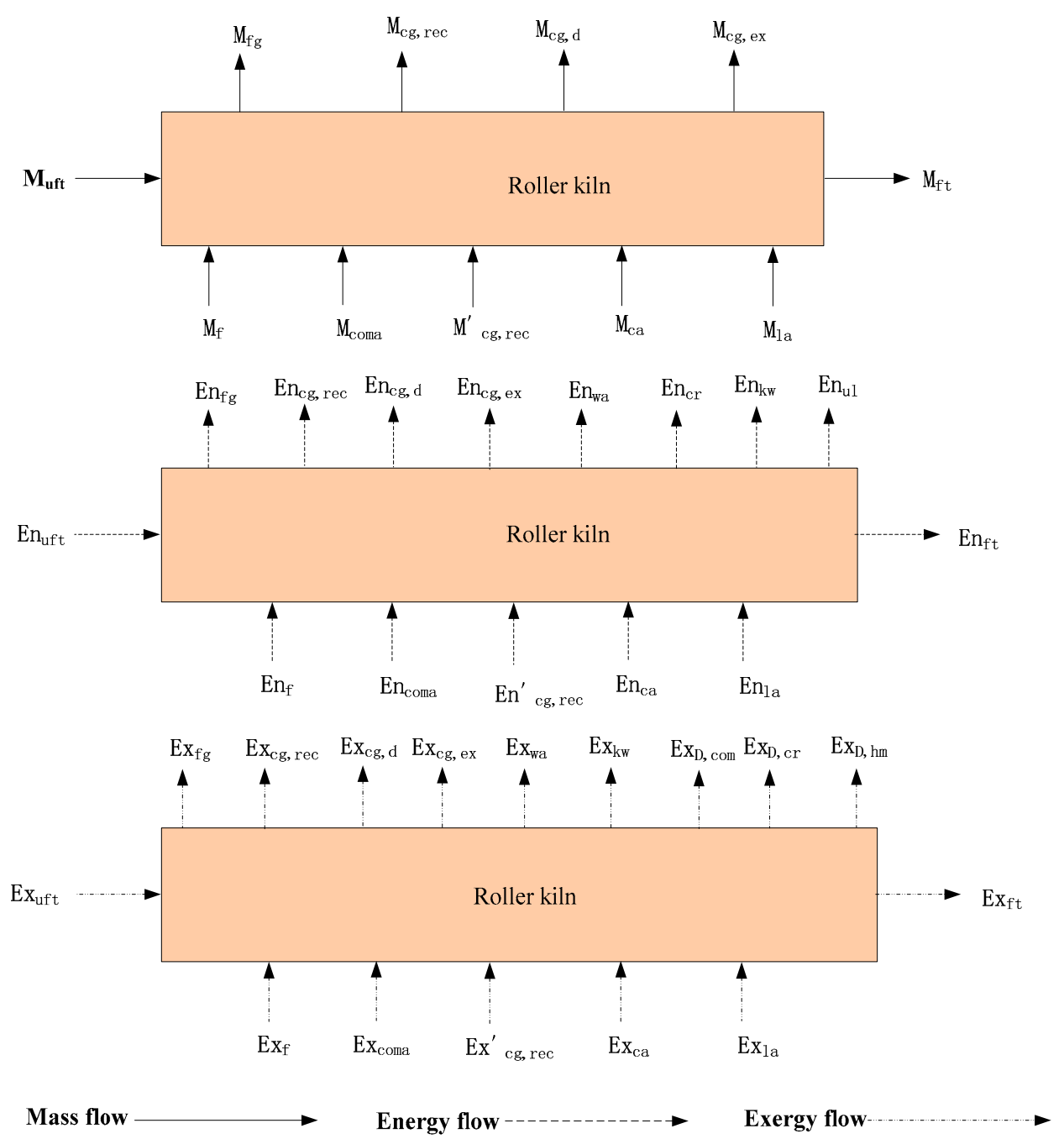

Figure 3. The mass, energy, and exergy flows of the roller kiln.

\subsection{Mass Balance}

The mass balance of the roller kiln is discussed in this section. Figure 3 shows that the inlets of the roller kiln include unfired tile, fuel, combustion air, recovered cooling gas, cooling air (rapid cooling air and slow cooling air) and leakage air. The outlets are fired tile, flue gas, exhausted cooling gas, recovered cooling gas and cooling gas for drying. The mass balance of the roller kiln is described as follows:

$$
\dot{m}_{u f t}+\dot{m}_{f}+\dot{m}_{c o m a}+\dot{m}_{c g, r e c}^{\prime}+\dot{m}_{c a}+\dot{m}_{l a}=\dot{m}_{f t}+\dot{m}_{f g}+\dot{m}_{c g, r e c}+\dot{m}_{c g, d}+\dot{m}_{c g, e x}
$$

where $\dot{m}_{u f t}, \dot{m}_{f}, \dot{m}_{c o m a}, \dot{m}_{c g, r e c}, \dot{m}_{c a}$ and $\dot{m}_{l a}$ stand for the mass flows of the unfired tile, fuel, combustion air, recovered cooling gas, cooling air and leakage air, and $\dot{m}_{f t}, \dot{m}_{f g}, \dot{m}_{c g, r e c}, \dot{m}_{c g, d}$ and $\dot{m}_{c g, e x}$ stand for the mass flows of the fired tile, flue gas, recovered cooling gas, cooling gas for drying and exhausted cooling gas, respectively.

The unfired tile enters the kiln at a rate of $9074 \mathrm{~kg} / \mathrm{h}$. After the firing process, there is a mass loss of $363 \mathrm{~kg} / \mathrm{h}$, due to the evaporation of water and volatile matter. Then, the tile is discharged from the $\mathrm{kiln}$ at a rate $8711 \mathrm{~kg} / \mathrm{h}$.

In the system, the mixed gases (fuel, combustion air, cooling air, flue gas and cooling gas) are assumed to be ideal gases, so the density can be determined using the ideal gas equation. The mass flow of the gas can be estimated because the gas's volume flow can be obtained. According to the mass 
balance, leakage air is equal to the mass difference of the inlets and outlets of the roller kiln, which is evaluated to be $486 \mathrm{~kg} / \mathrm{h}$. The mass balance of the roller kiln is presented in Table 5 .

Table 5. Mass balance of the roller kiln.

\begin{tabular}{cccc}
\hline Input Matter & Amount $\mathbf{( k g} / \mathbf{h})$ & Output Matter & Amount $\mathbf{k g} / \mathbf{h})$ \\
\hline Unfired tile & 9074 & Fired tile & 8711 \\
Fuel (water-gas) & 3591 & Flue gas & 11,492 \\
Combustion air & 4044 & Exhausted cooling gas & 30,099 \\
Recovered cooling gas & 3008 & Recovered cooling gas & 3008 \\
Cooling air & 51,151 & Cooling gas for drying & 18,043 \\
Leakage air & 486 & - & - \\
Total & 71,354 & Total & 71,354 \\
\hline
\end{tabular}

\subsection{Energy Analysis}

\subsubsection{Energy Balance}

In the firing process, the main energy consumption is thermal energy; other forms of energy, such as electrical energy, are not considered in this case. In the roller kiln, the input energy flows include unfired tile, fuel, combustion air, recovered cooling gas, cooling air and leakage air. The output energy flows consist of fired tile, flue gas, exhausted cooling gas, recovered cooling gas, cooling gas for drying, latent heat of water, enthalpy of the calcination reaction, heat loss through the kiln wall and uncountable energy losses. The energy balance for the control volume can be expressed as follows:

$$
\begin{gathered}
\sum \dot{E} n_{i n}=\sum \dot{E} n_{o u t} \\
\sum \dot{E} n_{i n}=\dot{E n_{u f t}}+\dot{E n_{f}}+\dot{E} n_{c o m a}+\dot{E n_{c g, r e c}^{\prime}}+\dot{E n_{c a}}+\dot{E n_{l a}} \\
\sum \dot{E} n_{o u t}=\dot{E} n_{f t}+\dot{E} n_{f g}+\dot{E} n_{c g, r e c}+\dot{E} n_{c g, d}+\dot{E} n_{c g, e x}+\dot{E} n_{w a}+\dot{E} n_{c r}+\dot{E} n_{k w}+\dot{E} n_{u_{l}}
\end{gathered}
$$

where $\dot{E n_{f}}$ is the energy of the fuel that includes two items: physical and chemical energy. Here, the chemical energy of the fuel can be calculated by Equation (2) (Table 1), of which the low heating value is evaluated to be $5638 \mathrm{~kJ} / \mathrm{kg}$. $\dot{E n_{u f t}}, \dot{E n_{c o m a}}, \dot{E n_{c g}, r e c}, \dot{E n_{c a}}, \dot{E n_{l a}}, \dot{E n_{f t}}, \dot{E n_{f g}}, \dot{E n_{c g}, r e c}, \dot{E n_{c g, d}}, \dot{E n_{c g, e x}}$ and the physical energy of the fuel can be determined using Equation (1) (Table 1).

The specific heat capacity is a function of the temperature, which can be calculated by [27]:

$$
C_{p}=a+b T+c T^{2}+d T^{3}
$$

where $C_{p}$ means the specific heat capacity in $\mathrm{kJ} / \mathrm{kmol} \cdot \mathrm{K}$. The coefficients $a, b, c$ and $d$ are summarized in Table 6.

Table 6. The coefficients of specific heat capacity.

\begin{tabular}{cccccc}
\hline Material & $\mathbf{a}$ & $\mathbf{b}$ & $\mathbf{c}$ & $\mathbf{d}$ & Temperature Range (K) \\
\hline $\mathrm{CO}$ & 28.16 & $0.1675 \times 10^{-2}$ & $0.5372 \times 10^{-5}$ & $-2.222 \times 10^{-9}$ & $273-1500$ \\
$\mathrm{H}_{2}$ & 29.11 & $-0.1916 \times 10^{-2}$ & $0.4003 \times 10^{-5}$ & $-0.8704 \times 10^{-9}$ & $273-1500$ \\
$\mathrm{CH}_{4}$ & 19.89 & $5.024 \times 10^{-2}$ & $1.269 \times 10^{-5}$ & $-11.01 \times 10^{-9}$ & $273-1500$ \\
$\mathrm{O}_{2}$ & 25.48 & $1.520 \times 10^{-2}$ & $-0.71559 \times 10^{-5}$ & $1.312 \times 10^{-9}$ & $273-1500$ \\
$\mathrm{~N}_{2}$ & 28.9 & $-0.1571 \times 10^{-2}$ & $0.8081 \times 10^{-5}$ & $-2.873 \times 10^{-9}$ & $273-1500$ \\
$\mathrm{CO}_{2}$ & 22.26 & $5.981 \times 10^{-2}$ & $-3.501 \times 10^{-5}$ & $7.469 \times 10^{-9}$ & $273-1500$ \\
$\mathrm{H}_{2} \mathrm{O}$ & 32.24 & $0.1923 \times 10^{-2}$ & $1.005 \times 10^{-5}$ & $-3.595 \times 10^{-9}$ & $273-1500$ \\
$\mathrm{NO}$ & 29.34 & $-0.09395 \times 10^{-2}$ & $0.9747 \times 10^{-5}$ & $-4.187 \times 10^{-9}$ & $273-1500$ \\
$\mathrm{NO}_{2}$ & 22.9 & $5.715 \times 10^{-2}$ & $-3.52 \times 10^{-5}$ & $7.87 \times 10^{-9}$ & $273-1500$ \\
\hline
\end{tabular}


The specific heat capacity of a gas mixture can be calculated as:

$$
C_{p, g m}=\frac{1}{n} \sum C_{p}
$$

For the unfired and fired tile, the specific heat capacity can be calculated as [34]:

$$
C_{p, t i l e}=0.84+2.6 \times 10^{-4} \times(T-273)
$$

\subsubsection{Reaction Enthalpy}

In order to determine the reaction enthalpy, the chemical composition should be firstly known. The mineral formula and chemical composition of the unfired tile is shown in Table 7.

\begin{tabular}{|c|c|c|c|}
\hline \multicolumn{2}{|c|}{ Mineral Formula } & \multicolumn{2}{|c|}{ Chemical Composition } \\
\hline Term & Mass Percentage & Term & Mass Percentage \\
\hline Kaolin & $21 \%$ & $\mathrm{SiO}_{2}$ & $69.30 \%$ \\
\hline Illite & $15 \%$ & $\mathrm{Al}_{2} \mathrm{O}_{3}$ & $19.80 \%$ \\
\hline Quartz & $26 \%$ & $\mathrm{Fe}_{2} \mathrm{O}_{3}$ & $0.28 \%$ \\
\hline Potassium feldspar & $7 \%$ & $\mathrm{CaO}$ & $0.36 \%$ \\
\hline Albite & $31 \%$ & $\mathrm{MgO}$ & $0.16 \%$ \\
\hline \multirow[t]{4}{*}{ Total } & $100 \%$ & $\mathrm{~K}_{2} \mathrm{O}$ & $1.12 \%$ \\
\hline & & $\mathrm{Na}_{2} \mathrm{O}$ & $5.05 \%$ \\
\hline & & IL & $3.93 \%$ \\
\hline & & Total & $100 \%$ \\
\hline
\end{tabular}

Table 7. Mineral formula and chemical composition of the unfired tile.

In the firing process, the dominant chemical reactions include the dehydration and decomposition of kaolin, the dehydration of mica, the transformation of quartz crystal, the formation of mullite and glassy phase formation. The main chemical reactions are detailed as follows:

$$
\begin{gathered}
\text { R-1: } \mathrm{Al}_{2} \mathrm{O}_{3} \cdot 2 \mathrm{SiO}_{2} \cdot 2 \mathrm{H}_{2} \mathrm{O}(\mathrm{s}) \rightarrow \mathrm{Al}_{2} \mathrm{O}_{3} \cdot 2 \mathrm{SiO}_{2}(\mathrm{~s})+2 \mathrm{H}_{2} \mathrm{O}(\mathrm{g}) \\
\text { R-2: } \mathrm{KAl}_{2}\left(\mathrm{AlSi}_{3} \mathrm{O}_{10}\right)(\mathrm{OH})_{2}(\mathrm{~s}) \rightarrow \mathrm{KAlSi}_{3} \mathrm{O}_{8}(\mathrm{~s})+\mathrm{Al}_{2} \mathrm{O}_{3}(\mathrm{~s})+\mathrm{H}_{2} \mathrm{O}(\mathrm{g}) \\
\mathrm{R}-3: \alpha-\mathrm{SiO}_{2}(\mathrm{~s}) \rightarrow \beta-\mathrm{SiO}_{2}(\mathrm{~s}) \\
\mathrm{R}-4: \mathrm{Al}_{2} \mathrm{O}_{3} \cdot 2 \mathrm{SiO}_{2}(\mathrm{~s}) \rightarrow(1 / 3) 3 \mathrm{Al}_{2} \mathrm{O}_{3} \cdot 2 \mathrm{SiO}_{2}(\mathrm{~s})+(4 / 3) \mathrm{SiO}_{2}(\mathrm{~s}) \\
\mathrm{R}-5: \mathrm{K}\left(\mathrm{AlSi}_{3} \mathrm{O}_{8}\right)(\mathrm{s}) \rightarrow \mathrm{K}\left(\mathrm{AlSi}_{3} \mathrm{O}_{8}\right)(\mathrm{l}) \\
\text { R-6: } \mathrm{Na}\left(\mathrm{AlSi}_{3} \mathrm{O}_{8}\right)(\mathrm{s}) \rightarrow \mathrm{Na}\left(\mathrm{AlSi}_{3} \mathrm{O}_{8}\right)(\mathrm{l})
\end{gathered}
$$

The energy of the chemical reactions can be estimated according to the Equation (4) (Table 1), in which $q$ is the chemical reaction heat. The enthalpies of the matters participating in the above chemical reaction are listed in Table $8[35,36]$. This reaction enthalpy is determined to be $2,622,882 \mathrm{~kJ} / \mathrm{h}$. 
Table 8. The entropy and enthalpy of the substances participating in the chemical reactions.

\begin{tabular}{|c|c|c|c|c|c|c|c|c|c|}
\hline & $\mathbf{T}(\mathbf{K})$ & $\mathrm{N}(\mathrm{mol})$ & 'S(kJ/mol·K) & $\triangle \mathbf{H}_{\mathrm{F}}(\mathrm{kJ} / \mathrm{mol})$ & & $\mathbf{T}(\mathbf{K})$ & $\mathrm{N}(\mathrm{mol})$ & $\mathrm{S}(\mathrm{kJ} / \mathrm{mol} \cdot \mathrm{K})$ & $\Delta \mathbf{H}_{\mathrm{F}}(\mathrm{kJ} / \mathrm{mol})$ \\
\hline $\mathrm{R}-1$ & & & & & $\mathrm{R}-4$ & & & & \\
\hline Reactants & & & & & Reactants & & & & \\
\hline $\begin{array}{c}\mathrm{Al}_{2} \mathrm{O}_{3} \cdot 2 \mathrm{SiO}_{2} \cdot 2 \mathrm{H}_{2} \mathrm{O}(\mathrm{s}) \\
\text { Products }\end{array}$ & 823 & 1 & 0.511 & -4110.446 & $\begin{array}{l}\mathrm{Al}_{2} \mathrm{O}_{3} \cdot 2 \mathrm{SiO}_{2}(\mathrm{~s}) \\
\text { Products }\end{array}$ & 1373 & 1 & 0.504 & -3466.882 \\
\hline $\mathrm{Al}_{2} \mathrm{O}_{3} \cdot 2 \mathrm{SiO}_{2}(\mathrm{~s})$ & 823 & 1 & 0.374 & -3333.506 & $3 \mathrm{Al}_{2} \mathrm{O}_{3} \cdot 2 \mathrm{SiO}_{2}(\mathrm{~s})$ & 1373 & 0.3 & 0.98 & -6848.779 \\
\hline $\mathrm{H}_{2} \mathrm{O}(\mathrm{g})$ & 823 & 2 & 0.224 & -246.444 & $\mathrm{SiO}_{2}(\mathrm{~s})$ & 1373 & 1.3 & 0.142 & -899.91 \\
\hline$\Delta \mathrm{S}(\mathrm{kJ} / \mathrm{mol} \cdot \mathrm{K})$ & & & 0.311 & & $\triangle \mathrm{S}(\mathrm{kJ} / \mathrm{mol} \cdot \mathrm{K})$ & & & 0.012 & \\
\hline Qr(kJ/mol) & & & & 284.052 & $\mathrm{Qr}(\mathrm{kJ} / \mathrm{mol})$ & & & & -15.924 \\
\hline Reactants & & & & & Reactants & & & & \\
\hline $\begin{array}{c}\mathrm{KAl}_{2}\left(\mathrm{AlSi}_{3} \mathrm{O}_{10}\right)(\mathrm{OH})_{2}(\mathrm{~s}) \\
\text { Products }\end{array}$ & 873 & 1 & 0.778 & -5958.991 & $\begin{array}{l}\mathrm{K}\left(\mathrm{AlSi}_{3} \mathrm{O}_{8}\right)(\mathrm{s}) \\
\text { Products }\end{array}$ & 1393 & 1 & 0.669 & -4015.322 \\
\hline $\mathrm{KAlSi}_{3} \mathrm{O}_{8}(\mathrm{~s})$ & 873 & 1 & 0.507 & -3980.799 & $\mathrm{~K}\left(\mathrm{AlSi}_{3} \mathrm{O}_{8}\right)(\mathrm{l})$ & 1393 & 1 & 0.697 & -3976.728 \\
\hline $\mathrm{Al}_{2} \mathrm{O}_{3}(\mathrm{~s})$ & 873 & 1 & 0.167 & -1672.958 & $\triangle \mathrm{S}(\mathrm{kJ} / \mathrm{mol} \cdot \mathrm{K})$ & & & 0.028 & \\
\hline $\mathrm{H}_{2} \mathrm{O}(\mathrm{g})$ & 873 & 1 & 0.229 & -247.186 & Qr(kJ/mol) & & & & 38.594 \\
\hline$\Delta S(\mathrm{~kJ} / \mathrm{mol} \cdot \mathrm{K})$ & & & 0.125 & & R-6 & & & & \\
\hline Qr(kJ/mol) & & & & 58.048 & Reactants & & & & \\
\hline $\mathrm{R}-3$ & & & & & $\mathrm{Na}\left(\mathrm{AlSi}_{3} \mathrm{O}_{8}\right)(\mathrm{s})$ & 1413 & 1 & 0.637 & -4019.502 \\
\hline Products & & & & & $\mathrm{Na}\left(\mathrm{AlSi}_{3} \mathrm{O}_{8}\right)(\mathrm{l})$ & 1413 & 1 & 0.666 & -3988.88 \\
\hline$\beta-\mathrm{SiO}_{2}(\mathrm{~s})$ & 846 & 1 & 0.105 & -906.328 & $\Delta \mathrm{S}(\mathrm{kJ} / \mathrm{mol} \cdot \mathrm{K})$ & & & 0.029 & \\
\hline$\Delta S(\mathrm{~kJ} / \mathrm{mol} \cdot \mathrm{K})$ & & & 0.001 & & $\mathrm{Qr}(\mathrm{kJ} / \mathrm{mol})$ & & & & 30.622 \\
\hline Qr(kJ/mol) & & & & 0.728 & & & & & \\
\hline
\end{tabular}




\subsubsection{Kiln Wall Heat Loss}

The cross-section of the roller kiln is idealized as a rectangle with a width of $4.07 \mathrm{~m}$ and a height of $2.81 \mathrm{~m}$. The kiln wall is composed of internal fire bricks and an external insulation layer. The former is made of lightweight high alumina bricks with a thickness of $0.113 \mathrm{~m}$, while the latter includes aluminum silicate refractory fiber felt with $0.119 \mathrm{~m}$ thickness and an aluminum silicate refractory fiber with $0.078 \mathrm{~m}$ thickness. The composition of the kiln bottom is similar to that of the kiln wall, except that the thicknesses of the three corresponding materials are $0.13 \mathrm{~m}, 0.13 \mathrm{~m}$ and $0.10 \mathrm{~m}$, respectively. The lightweight high alumina bricks of the kiln roof are shaped like a rectangle with dimensions of $0.30 \times 3.68 \mathrm{~m}$. The external insulation layer of the kiln roof is an aluminum silicate refractory fiber bundle, with $0.15 \mathrm{~m}$ width and $4.07 \mathrm{~m}$ length, that prevents heat loss. Figure 4 shows the dimensions and materials of the cross-section of the roller kiln.

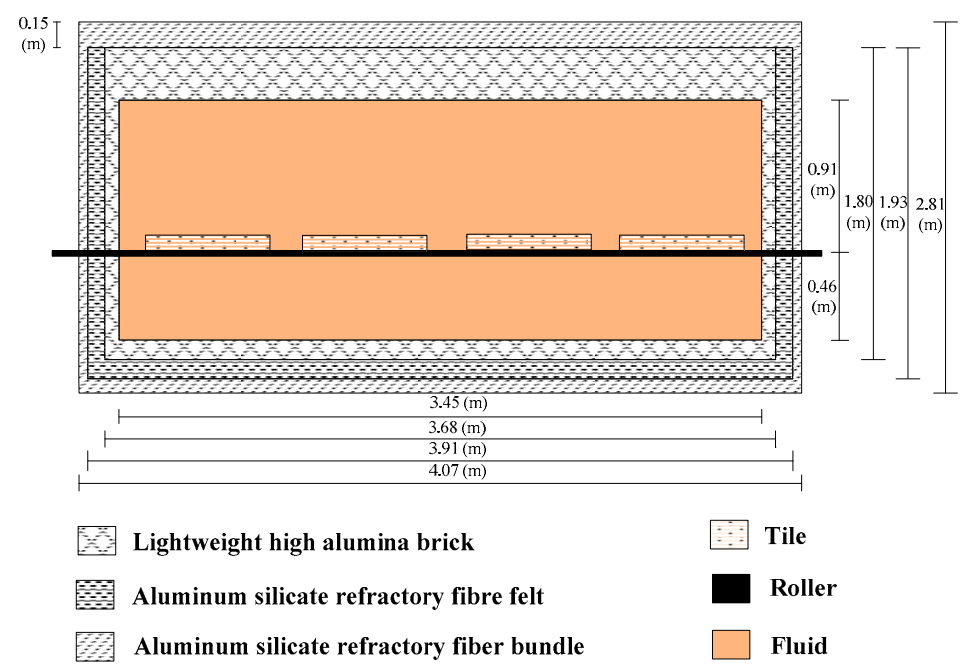

Figure 4. The cross-section of the roller kiln.

Kiln wall heat loss is regarded as an invalid heat, which could be detrimental to the thermal efficiency of the system. To accurately evaluate this heat loss, it is recommended to divide the control volume into smaller areas and determine the mean emissivity and surface temperature for each part. The Model $\mathrm{S}$ thermocouple, capable of measuring temperatures from $0^{\circ} \mathrm{C}$ to $1600^{\circ} \mathrm{C}$, with an error rate of $\pm 1.5 \%$, was applied to acquire the kiln temperature value. A HIMA infrared thermometer with a measuring span from $-50^{\circ} \mathrm{C}$ to $380^{\circ} \mathrm{C}$ and a deviation of $\pm 1.5^{\circ} \mathrm{C}$ was used to measure the surface temperature of the kiln. According to Equations in Table 2, the total heat loss of the kiln can be calculated as $2,718,276 \mathrm{~kJ} / \mathrm{h}$.

Besides, considering the heat loss of the pipeline, the recovered cooling gas is recycled as oxidizing air at a temperature of $471 \mathrm{~K}$ and energy of $631,799 \mathrm{~kJ} / \mathrm{h}$. $E n_{u_{l}}$ means uncountable energy losses, according to the energy balance, which can be determined as the difference between the input and output of energy flows in the roller kiln.

In the system, energy efficiency can be calculated by Equation (5), which is determined to be $13.4 \%$. The obtained results of the energy balance for the roller kiln are summarized in Table 9 and Figure 5 . 
Table 9. Energy balance of the roller kiln.

\begin{tabular}{|c|c|c|c|c|c|c|}
\hline & Term & $\mathbf{T}_{0}(\mathrm{~K})$ & $\mathrm{T}(\mathrm{K})$ & $\begin{array}{c}\mathrm{C}_{P} \\
(\mathrm{~kJ} /(\mathrm{kg} \cdot \mathrm{K}))\end{array}$ & m (kg/h) & $\underset{(\mathrm{kJ} / \mathrm{h})}{\operatorname{Amount}}$ \\
\hline \multirow[t]{8}{*}{ Input flow } & Unfired tile & 298 & 315 & 0.851 & 9074 & $131,261.217$ \\
\hline & $\begin{array}{l}\text { Fuel (water-gas) } \\
\text { sensible heat }\end{array}$ & 298 & 300 & 1.446 & 3591 & $103,86.102$ \\
\hline & $\begin{array}{l}\text { Fuel (water-gas) } \\
\text { combustion heat }\end{array}$ & - & - & - & - & $19,233,755.100$ \\
\hline & Combustion air & 298 & 300 & 1.143 & 4044 & 9242.054 \\
\hline & Recovered cooling gas & 298 & 471 & 1.214 & 3008 & $631,799.484$ \\
\hline & Cooling air & 298 & 300 & 1.143 & 51,151 & $116,898.402$ \\
\hline & Leakage air & 298 & 300 & 1.143 & 486 & 1110.692 \\
\hline & Total & - & - & - & 71,354 & $20,134,453.051$ \\
\hline \multirow[t]{10}{*}{ Output flow } & Fired tile & 298 & 392 & 0.871 & 8711 & $713,155.284$ \\
\hline & Flue gas & 298 & 540 & 1.151 & 11,492 & $3,200,698.681$ \\
\hline & Exhausted cooling gas & 298 & 420 & 1.193 & 30,099 & $4,380,848.522$ \\
\hline & Cooling gas for drying & 298 & 450 & 1.206 & 18,043 & $3,307,497.612$ \\
\hline & Recovered cooling gas & 298 & 491 & 1.222 & 3008 & $709,484.631$ \\
\hline & Latent heat of the water & - & - & - & - & $74,063.875$ \\
\hline & Reaction enthalpy & - & - & - & - & $2,622,881.905$ \\
\hline & Kiln wall heat loss & & - & - & - & $2,718,276.253$ \\
\hline & $\begin{array}{c}\text { Uncountable energy } \\
\text { losses }\end{array}$ & - & - & - & - & $2,407,546,288$ \\
\hline & Total & - & - & - & 71,354 & $20,134,453.051$ \\
\hline
\end{tabular}

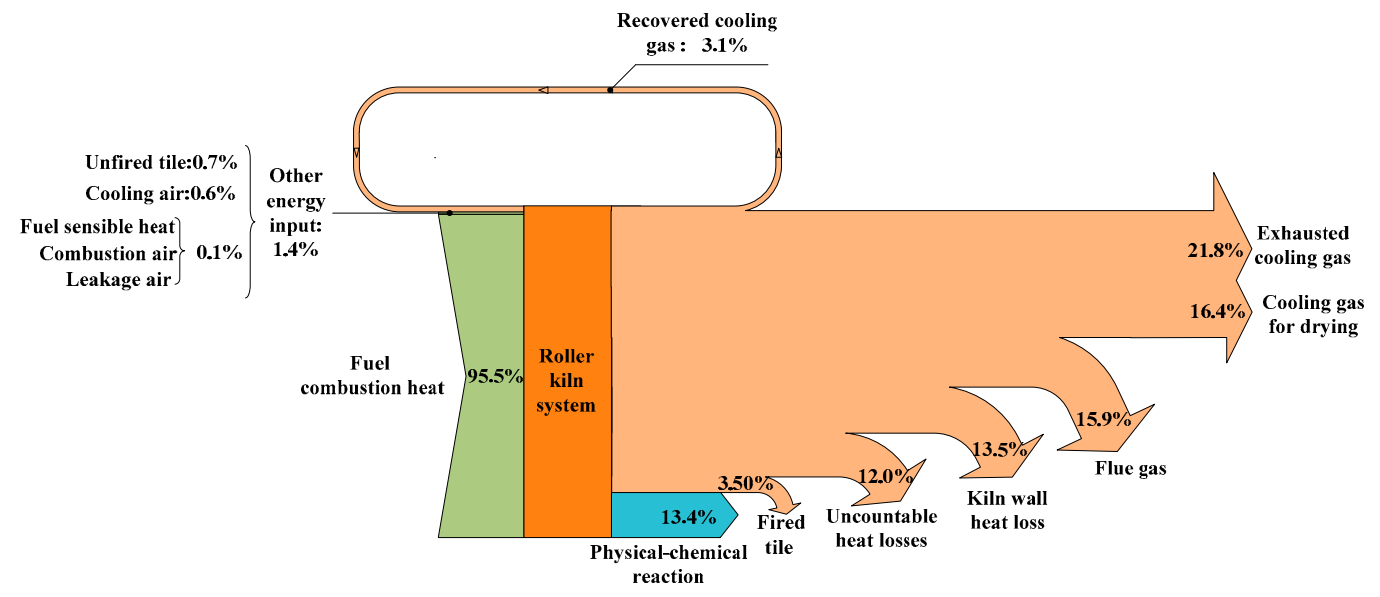

Figure 5. Sankey diagram for the roller kiln.

As depicted, the energy input is determined to be $20,134,453 \mathrm{~kJ} / \mathrm{h}$, which is dominated by the fuel combustion with a contribution of $95.5 \%$ while the recovered cooling gas accounts for $3.1 \%$. The result reveals that only $13.4 \%$ of the energy input is used in the physical-chemical reactions, which indicates the kiln's poor thermal performance. Cooling gas is found to be the leading factor resulting in the low energy efficiency, with an energy loss of $8,397,831 \mathrm{~kJ} / \mathrm{h}$, accounting for $41.7 \%$ of the total energy input. In the cooling system, the efficiency is a function of the heat transfer between cooling gas and high- temperature tile. The mass flow, temperature and residence time of the cooling air are the direct parameters affecting the absorbed heat by the cooling air. Therefore, the optimization of working conditions in the cooling zone will be beneficial to improve kiln efficiency and energy conservation. Besides, although $8.5 \%$ of the cooling gas is recycled to the kiln itself as oxidizing air and $39.4 \%$ is used for other plant facilities, such as the dryers, more than $50 \%$ of the heat-rich and pollution-free cooling gas is still released directly into the atmosphere. Therefore, minimizing or recycling this energy loss by applying heat recovery systems is still essential. The next factor of energy loss is flue gas, which accounts for $15.9 \%$ of the total energy input. The air excess coefficient has a great effect on combustion condition and fuel gas emission. On the one hand, increasing the air excess coefficient reduces the combustion temperature, decreasing the heat transfer rate, and thus, 
resulting in a decline in the physical-chemical reactions rate. Besides, the excess air also leads to an increase in energy loss, due to the increase in the amount of flue gas. On the other hand, reducing the coefficient of excess air leads to incomplete combustion, which results in the heat released decrease during combustion, thus, consuming more fuel. In this study, the excess air coefficient is 1.26. In other words, the supply of combustion air is $26 \%$ greater than the ideal value. Thus, under the premise of providing at least sufficient oxygen to ensure product quality and stability, reducing the air excess coefficient will reduce flue gas, thereby decreasing energy loss due to flue gas emissions. Kiln wall energy loss and uncontrolled heat losses are $13.5 \%$ and $12 \%$, respectively. These relatively high values could be due to the insufficient insulation of the system. Thus, enhancing the insulation could be effective for better thermal performance.

\subsection{Exergy Analysis}

\subsubsection{Exergy Balance}

In order to investigate the qualitative and quantitative aspects, exergy analysis is applied to the roller kiln. Exergy is defined that the maximum theoretical useful work (shaft work or electrical work) is produced when the system and the external environment reach complete thermodynamic equilibrium while interacting with each other in Ref. [30]. The exergy balance for the roller kiln consists of the input flows of unfired tile, fuel, combustion air, recovered cooling gas, cooling air, leakage air and the output flows of fired tile, flue gas, exhausted cooling gas, recovered cooling gas, cooling gas for drying, latent heat of water, and wall heat loss.

$$
\begin{gathered}
\sum \dot{E} x_{i n}=\sum \dot{E} x_{o u t}+\sum \dot{E x_{D}} \\
\sum \dot{E} x_{i n}=\dot{E} x_{u f t}+\dot{E} x_{f}+\dot{E} x_{c o m a}+\dot{E x_{c g, r e c}^{\prime}}+\dot{E} x_{c a}+\dot{E} x_{l a} \\
\sum \dot{E} x_{o u t}=\dot{E} x_{f t}+\dot{E} x_{f g}+\dot{E} x_{c g, r e c}+\dot{E} x_{c g, d}+\dot{E} x_{c g, e x}+\dot{E} x_{w a}+\dot{E} x_{k w}
\end{gathered}
$$

The exergy of any substance includes both physical and chemical exergy, which can be assessed by Equation (7). In the present paper, the physical exergy of the matter can be calculated using Equation (1) (Table 3).

The fuel's chemical exergy can be determined according to Equation (3) (Table 3), in which the $\phi$ represents the relation between the chemical exergy and the $L H V$ that can be determined to be 0.95 for this fuel [30]. The chemical exergy of a gas mixture, such as air and combustion products, can be calculated using Equation (4) (Table 3).

The exergy loss through the kiln wall can be determined using Equation (6) (Table 3) [30]. The symbol $Q$ in the Equation (6) (Table 3) means the amount of the exchanged heat through the kiln to the atmosphere, which is determined to be $2,718,276 \mathrm{~kJ} / \mathrm{h}$. The exergy los through the kiln wall is evaluated as $423,867 \mathrm{~kJ} / \mathrm{h}$.

\subsubsection{Exergy Destruction}

Exergy destruction, which is proportional to entropy generation, is caused by the irreversibility of the process. In the roller kiln, entropy generation is due to three aspects: Combustion of the fuel, calcination of the tile and heat and mass transfer in the kiln. Performing the calculation of Equation (7) (Table 3) to evaluate exergy destruction requires first determining the entropy generation $S_{\text {gen }}$, which can be expressed as follows [18]:

$$
S_{\text {gen }}=\left(S_{p}-S_{r}\right)-S_{\text {loss }}
$$

where $S_{p}$ and $S_{r}$ stand for the entropy of products and reactants, respectively. $S_{\text {loss }}$ means entropy due to heat loss. 


\section{Exergy Destruction of Fuel Combustion}

In the roller kiln, the entropy values of the matters associated with combustion are shown in Table 10. The entropy change of combustion is equal to the difference between the products (combustion gas) and reactants (fuel and oxidizing air), which is $21,396 \mathrm{~kJ} / \mathrm{h}$. Entropy, due to the heat loss in this process, is given by [18]:

$$
\dot{S}_{\text {loss }}=\frac{\dot{Q}_{\text {loss }}}{T}
$$

In the combustion process, $T$ is the boundary temperature at which heat is lost to its surroundings (gases and solids), close to the combustion temperature. Thus, the value of the combustion temperature is considered to be the surrounding temperature. $Q_{\text {loss }}$ is the heat loss accompanied by heat transfer in the combustion process, which can be determined as the difference between the heat generated by fuel combustion and the heat of the combustion gases at the combustion temperature [18]:

$$
\dot{Q}_{\text {loss }}=\dot{m}_{f} \cdot L H V+\dot{m}_{\text {comg }} \cdot c_{p, c o m g} \cdot T_{\text {com }}
$$

The entropy due to heat loss is calculated as $469 \mathrm{~kJ} / \mathrm{h}$. In the combustion process, the total entropy is $20,927 \mathrm{~kJ} / \mathrm{h}$, and the exergy destruction because of the combustion is estimated to be $6,236,292 \mathrm{~kJ} / \mathrm{h}$.

\section{Exergy Destruction of Calcination Reaction}

As for the calcinations in this case, the main sources of entropy generation are the physical-chemical reactions. The same method in the above discussion of the combustion process can be applied to determine the entropy of calcination. Table 8 presents the entropy values of the materials involved in the calcination reaction. The corresponding entropy change is $3226 \mathrm{~kJ} / \mathrm{kg} \cdot \mathrm{K}$. The entropy, due to the heat loss of the reacting system, is given by [18]:

$$
\dot{S}_{\text {loss }}=-\frac{\dot{Q}_{\text {reac }}}{T_{\text {reac }}}
$$

Based on the data in Table 8, Equation (48) can be used to calculate the entropy due to the heat loss of the dehydration and decomposition of kaolin, the dehydration of mica, the transformation of quartz crystal, the formation of mullite and the glassy phase formation, the obtained results are $-2548 \mathrm{~kJ} / \mathrm{kg} \cdot \mathrm{K},-227 \mathrm{~kJ} / \mathrm{kg} \cdot \mathrm{K},-34 \mathrm{~kJ} / \mathrm{kg} \cdot \mathrm{K}, 86 \mathrm{~kJ} / \mathrm{kg} \cdot \mathrm{K},-63 \mathrm{~kJ} / \mathrm{kg} \cdot \mathrm{K},-232 \mathrm{~kJ} / \mathrm{kg} \cdot \mathrm{K}$, respectively. Thus, the exergy destruction of the calcination reaction is $1,860,965 \mathrm{~kJ} / \mathrm{h}$.

\section{Exergy Destruction of the Heat and Mass Transfer}

The exergy destruction because of the heat and mass transfer is the difference between the total exergy destruction and the sum of exergy destruction caused by the fuel combustion and calcination reaction:

$$
\dot{E x_{D, h m t}}=\dot{E x_{D}}-\left(\dot{E x_{D, c o m}}+\dot{E x_{D, r e a c}}\right)
$$

The results for the exergy analysis of the roller kiln are displayed in Table 11 and Figure 6. As depicted, fuel combustion is the main source of exergy input, accounting for $99.1 \%$. In this system, $9.7 \%$ of the exergy input is used for physical-chemical reactions in the firing process, which is lower than its energy efficiency. This is because irreversible processes always destroy exergy, which means not all energy can be converted to useful work. 
Table 10. Entropy generation in the combustion process.

\begin{tabular}{|c|c|c|c|c|c|c|c|c|}
\hline & $\mathrm{T}(\mathrm{K})$ & M (kg/mol) & $\mathrm{Ni}(\mathrm{kmol})$ & $\mathrm{s}(\mathrm{kJ} / \mathrm{kmol \bullet K})$ & $x \mathbf{i}$ & $R \ln (\mathbf{x i} \cdot \mathbf{P})$ & $\mathrm{Ni} \cdot \mathrm{si}(\mathrm{kJ} / \mathrm{kg} \bullet \mathrm{K})$ & Total Entropy $(\mathrm{kJ} / \mathrm{kg} \bullet \mathrm{K})$ \\
\hline Fuel (water-gas) & & & & & & & & $28,803.190$ \\
\hline $\mathrm{CO}$ & 300 & 0.028 & 47.188 & 197.841 & 0.32 & -9.473 & 9782.837 & \\
\hline $\mathrm{H}_{2}$ & 300 & 0.002 & 22.334 & 130.658 & 0.15 & -15.773 & 3270.321 & \\
\hline $\mathrm{CH}_{4}$ & 300 & 0.016 & 2.955 & 186.434 & 0.02 & -32.525 & 647.047 & \\
\hline $\mathrm{O}_{2}$ & 300 & 0.032 & 0.295 & 205.329 & 0.002 & -51.668 & 75.771 & \\
\hline $\mathrm{N}_{2}$ & 300 & 0.028 & 70.488 & 191.789 & 0.478 & -6.137 & $13,951.351$ & \\
\hline $\mathrm{CO}_{2}$ & 300 & 0.044 & 4.425 & 214 & 0.03 & -29.154 & 1075.863 & \\
\hline Combustion air & & & & & & & & $28,175.358$ \\
\hline $\mathrm{N}_{2}$ & 300 & 0.028 & 109.417 & 191.789 & 0.7748 & -2.121 & $21,217.067$ & \\
\hline $\mathrm{O}_{2}$ & 300 & 0.032 & 29.068 & 205.329 & 0.2059 & -13.139 & 6350.326 & \\
\hline $\mathrm{CO}_{2}$ & 300 & 0.044 & 0.042 & 214 & 0.0003 & -67.441 & 11.925 & \\
\hline $\mathrm{H}_{2} \mathrm{O}(\mathrm{g})$ & 300 & 0.018 & 2.683 & 189.167 & 0.019 & -32.951 & 596.039 & \\
\hline $\begin{array}{c}\text { Recovered cooling } \\
\text { gas }\end{array}$ & & & & & & & & $22,543.714$ \\
\hline $\mathrm{N}_{2}$ & 471 & 0.03 & 81.393 & 206.74 & 0.77 & -2.121 & $16,999.795$ & \\
\hline $\mathrm{O}_{2}$ & 471 & 0.03 & 21.623 & 220.69 & 0.21 & -13.139 & 5056.098 & \\
\hline $\mathrm{CO}_{2}$ & 471 & 0.04 & 0.032 & 234.86 & 0.00 & -67.441 & 9.529 & \\
\hline $\mathrm{H}_{2} \mathrm{O}(\mathrm{g})$ & 471 & 0.02 & 1.996 & 206.66 & 0.02 & -32.951 & 478.293 & \\
\hline Combustion gas & & & & & & & & $100,918.179$ \\
\hline $\mathrm{CO}_{2}$ & 1413 & 0.04 & 30.88 & 292.18 & 0.08 & -21.220 & 9678.425 & \\
\hline $\mathrm{CO}$ & 1413 & 0.03 & 0.0001 & 246.05 & 0.00 & -131.449 & 0.020 & \\
\hline $\mathrm{NO}$ & 1413 & 0.03 & 0.0001 & 262.707 & 0.000000547 & -119.878 & 0.049 & \\
\hline $\mathrm{NO}_{2}$ & 1413 & 0.046 & 0.0001 & 315.82 & 0.000000145 & -130.917 & 0.025 & \\
\hline $\mathrm{N}_{2}$ & 1413 & 0.028 & 305.898 & 241.88 & 0.7715 & -2.157 & $74,650.284$ & \\
\hline $\mathrm{O}_{2}$ & 1413 & 0.032 & 34.836 & 258.067 & 0.0879 & -20.216 & 9694.323 & \\
\hline $\mathrm{H}_{2} \mathrm{O}$ & 1413 & 0.018 & 25.197 & 250.742 & 0.0636 & -22.906 & 6895.053 & \\
\hline Over total entropy & & & & & & & & $21,395.918$ \\
\hline
\end{tabular}


Table 11. Exergy flow of the roller kiln.

\begin{tabular}{|c|c|c|c|c|c|c|c|c|c|c|}
\hline & Term & To (K) & $\mathrm{T}(\mathrm{K})$ & $\begin{array}{c}C_{P} \\
(k J /(k g \bullet K))\end{array}$ & $\mathrm{m}(\mathrm{kg} / \mathrm{h})$ & $\begin{array}{c}\text { Enthalpy } \\
(\mathrm{kJ} / \mathrm{h})\end{array}$ & $\begin{array}{c}\text { Entropy } \\
(\mathrm{kJ} / \mathrm{kg} \bullet \mathrm{K})\end{array}$ & $\begin{array}{c}\text { Physical Exergy } \\
(\mathrm{kJ} / \mathrm{h})\end{array}$ & $\begin{array}{c}\text { Chemical } \\
\text { Exergy (kJ/h) }\end{array}$ & $\begin{array}{c}\text { Total Exergy } \\
(\mathbf{k J} / \mathrm{h})\end{array}$ \\
\hline \multirow[t]{7}{*}{ Input flow } & Unfired tile & 298 & 315 & 0.851 & 9074 & $131,261.217$ & 428.368 & 3607.464 & - & 3607.464 \\
\hline & Fuel (water-gas) & 298 & 300 & 1.446 & 3591 & $10,386.102$ & 34.736 & 34.698 & $19,233,755.100$ & $19,233,789.798$ \\
\hline & Combustion air & 298 & 300 & 1.143 & 4044 & 9242.054 & 30.910 & 30.876 & - & 30.876 \\
\hline & Recovered cooling gas & 298 & 471 & 1.214 & 3008 & $631,799.484$ & 1671.766 & $133,613.345$ & - & $133,613.345$ \\
\hline & Cooling air & 298 & 300 & 1.143 & 51,151 & $116,898.402$ & 390.966 & 390.530 & - & 390.530 \\
\hline & Leakage air & 298 & 300 & 1.143 & 486 & 1110.692 & 3.715 & 3.711 & - & 3.711 \\
\hline & Total & - & - & - & 71,354 & - & - & - & - & $19,371,435.724$ \\
\hline \multirow[t]{8}{*}{ Output flow } & Fired tile & 298 & 392 & 0.871 & 8711 & $713,155.284$ & 2080.049 & $93,300.670$ & - & $93,300.670$ \\
\hline & Flue gas & 298 & 540 & 1.151 & 11,492 & $3,200,698.681$ & 7862.551 & $857,658.364$ & - & $857,658.364$ \\
\hline & Exhausted cooling gas & 298 & 420 & 1.193 & 30,099 & $4,380,848.522$ & $12,322.437$ & $708,762.222$ & - & $708,762.222$ \\
\hline & Cooling gas for drying & 298 & 450 & 1.206 & 18,043 & $3,307,497.612$ & 8968.412 & $634,910.708$ & - & $634,910.708$ \\
\hline & Recovered cooling gas & 298 & 491 & 1.222 & 3008 & $709,484.631$ & 1835.656 & $162,459.147$ & - & $162,459.147$ \\
\hline & Latent heat of the water & - & - & - & - & - & - & - & - & $14,223.512$ \\
\hline & Kiln wall heat loss & - & - & - & - & - & - & - & - & $423,867.0236$ \\
\hline & Total & - & - & - & 71,354 & - & - & - & - & $2,895,181.646$ \\
\hline \multirow{4}{*}{$\begin{array}{c}\text { Exergy } \\
\text { destruction }\end{array}$} & Combustion & - & - & - & - & - & - & - & - & $6,236,292.406$ \\
\hline & Calcination reaction & - & - & - & - & - & - & - & - & $1,860,965$ \\
\hline & Heat and mass transfer & - & - & - & - & - & - & - & - & $8,378,996.672$ \\
\hline & Total & - & - & - & - & - & - & - & - & $16,476,254.08$ \\
\hline
\end{tabular}




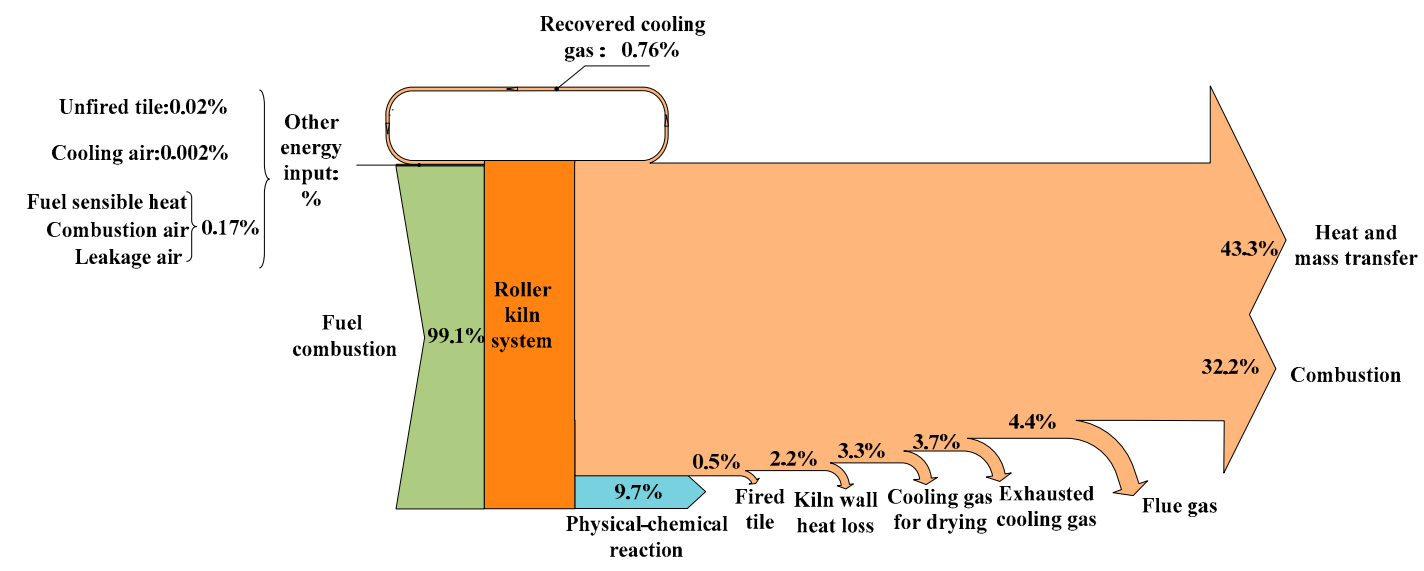

Figure 6. Grassmann diagram of the roller kiln.

In contrast to the result regarding energy analysis, the cooling gas did not contribute to the largest exergy loss. For the exergy analysis, exergy destruction is the key factor affecting the exergy efficiency of the process. The identified sources of exergy destruction in each subsystem are illustrated in Figure 7. As depicted, the exergy destruction of the heating system and cooling system accounts for $60.7 \%$ and $24.4 \%$, which indicate that the heating system is the main source of exergy destruction.

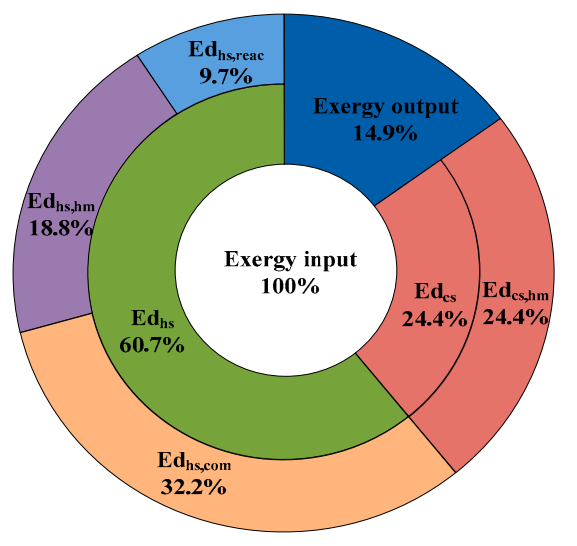

Figure 7. The sources of exergy destruction in the kiln subsystems.

The exergy destruction because of heat and mass transfer, combustion and calcination reaction accounts for $85.1 \%$ of the exergy input in the kiln. It is found that exergy destruction, due to heat and mass transfer is the main source of irreversibility, with a total of 8,378,997 kJ/h. The exergy destruction, due to heat and mass transfer, is mainly caused by the temperature difference between the ceramic tile and the gas. Obviously, reducing the temperature difference has positive impacts on the decline in exergy destruction of heat and mass transfer, but the temperature difference also drives the calcination process. This value can be selected by the optimization performance. Noted that, the cooling system accounts for $52.8 \%$ of the exergy destruction, due to heat and mass transfer. Therefore, a parameter study of the cooling system is still essential. This content involved is further investigated in Section 5.

The other major source of exergy destruction is fuel combustion, which accounts for $37.9 \%$ of the total exergy destruction. Combustion is an irreversible process that inevitably produces exergy destruction. This exergy loss could be minimized by making a better combustion condition [37], which could be achieved by the following methods: Increasing the temperature of the reactants, optimizing the air excess coefficient to make combustion close to stoichiometric conditions and using high-quality fuel with a simple molecular structure. 
The exergy loss through the flue and exhausted cooling gas account for $4.4 \%$ and $3.7 \%$ of the exergy input, respectively. These could be reduced through waste heat recovery applications or optimizing the air excess coefficient.

The exergy loss through the kiln wall is $423,867 \mathrm{~kJ} / \mathrm{h}$, corresponding to $2.2 \%$ of the total exergy input. The result indicates that the roller kiln has insufficient insulation. This may have a negative impact on the heat exchange between the tile and the gas, affecting the system thermal efficiency, and thus, leading to an increase in fuel consumption. Thus, it is necessary to improve insulation to reduce exergy loss.

In order to acquire discernment into present results investigation, a comparison is performed with previous research. Salvador Ferrer et al., [26] performed energy-exergy analysis on a roller kiln by using the same approach. In their case, the energy efficiency was determined as $15 \%$, which is found to be higher than the exergy efficiency of $10 \%$. The conclusion is similar to the current result (i.e., energy and exergy efficiencies are $13.4 \%$ and $9.7 \%$ in the present paper). This can be explained that exergy is destroyed by the entropy generation of the system. In addition, both the energy and exergy efficiency in their study is slightly higher than that in this study. These discrepancies are complicated, since there are some differences between the two analyses, namely, fuel selection (natural gas was applied as fuel in their case, but water-gas is the present fuel), material properties, kiln configurations, insulation situations and so on. Despite the efficiency differences are slight, both efficiencies are very low, which display the notable energy conservation potential.

Furthermore, the exergy destruction was determined as $83 \%$ of the total exergy input, while that is $85.1 \%$ in the present process. However, no specific investigation was performed for the sources of exergy destruction, in this respect, not enough attention was paid to identify the evitable and inevitable exergy destruction and the evitable exergy loss for the roller kiln. In the current work, exergy destruction (caused by heat and mass transfer, fuel combustion, and chemical reactions) are calculated. Since the study of exergy destruction sources plays an important role in the accurate verdict of energy conservation potential, the current research is worth promoting.

\section{Parametric Study of the Cooling System}

\subsection{Thermodynamic and Fuel-Saving Analysis}

\subsubsection{Change in Cooling Air Mass Flow}

Cooling air mass flow has an impact on the exit temperature of the fired tiles. An increase in the mass flow of the cooling gas could cause more heat exchange between the cooling gas and the fired tile, which means it can absorb more heat from the fired tile. This also could lead to a slight decrease in the outlet temperature of the cooling gas. The analysis revealed that for every $1 \%$ increase in cooling air mass flow, the outlet temperature of the recovered gas, cooling gas for drying and exhausted cooling gas decreased by $0.29 \%, 0.25 \%$, and $0.21 \%$, respectively. At the same time, every $1 \%$ increase in cooling air mass flow reduces the outlet temperature of the fired tiles by $2.81 \%$. On the other hand, more energy content in recovered cooling gas is carried back to the roller kiln system as oxidizing air, which also reduces fuel consumption.

Figure 8 shows the changes of energy and exergy efficiencies with the increase of cooling air mass flow. With a $1 \%$ increase in cooling air mass flow, the estimated variation of energy and exergy efficiencies increased by $0.06 \%$ and $0.04 \%$, respectively. Also, the estimated energy-saving is about $89,195 \mathrm{~kJ} / \mathrm{h}$, corresponding to the fuel consumption decrease of $0.44 \%$. It is noted that this could be achieved by adjusting the valve opening, thereby simply changing the operational parameter without additional investment. Therefore, an increase in cooling air mass flow is recommended to improve the thermal performance of the kiln. 


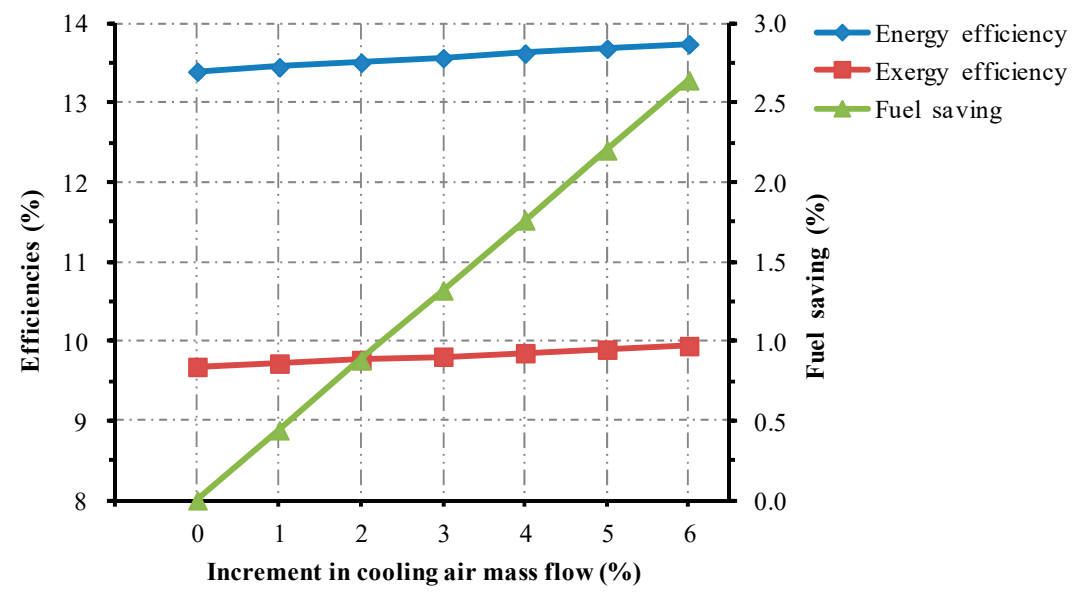

Figure 8. Impacts on energy and exergy efficiencies and fuel-saving of the roller kiln with changes in cooling air mass flow.

\subsubsection{Change in Cooling Air Temperature}

In the process of heat and mass transfer, exergy destruction is generated in the irreversible process through a finite temperature difference. It has been found that the reduction in temperature difference between the two mediums is beneficial for lowering exergy destruction, but temperature difference also drives heat transfer in the cooling system. With the given scope of temperatures (291-309 K), even though the lower temperature of cooling air causes a drop in exergy destruction, the heat exchange is also enhanced, and this effect overcomes the decreased amount of exergy destruction. Therefore, it is theoretically desirable to cool the fired tiles at a lower temperature. As depicted in Figure 9, for every $1 \%$ (a temperature change of $3{ }^{\circ} \mathrm{C}$ ), the studied kiln performs approximately $0.09 \%$ and $0.07 \%$ drops in energy and exergy efficiencies, respectively. Theoretically, if the cooling air temperature is close to the value of $291 \mathrm{~K}$, the energy and exergy efficiencies can be improved to $13.7 \%$ and $9.91 \%$, respectively. This situation also results in a decrease in fuel consumption of $2.3 \%$.

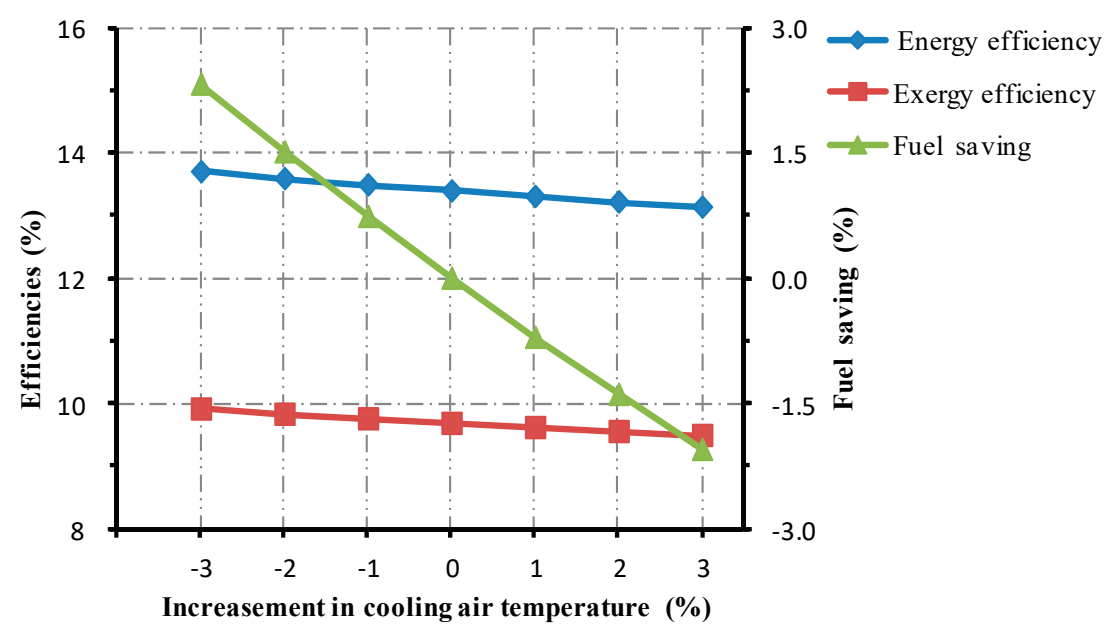

Figure 9. Impacts on energy and exergy efficiencies and fuel-saving of the roller kiln with changes in cooling air temperature.

\subsubsection{The Residence Time of the Cooling Air}

Variation in the cooling air residence time could affect the heat exchange between the cooling air and the fired tiles. An increase in the residence time of cooling air reduces the outlet temperature of the tiles. The fired tiles experience at roughly $3.9 \%$ decrease in outlet temperature with a $1 \%$ increase in the residence time of the cooling air. The thermal analysis for the roller kiln, shown in Figure 10, 
revealed the change of the energy and exergy efficiencies with variations in cooling air residence time. As depicted, for every $1 \%$ increase in the residence time, the studied kiln experiences approximately $0.16 \%$ and $0.12 \%$ rises in energy and exergy efficiencies, respectively, and the corresponding fuel consumption decreases by $1.18 \%$.

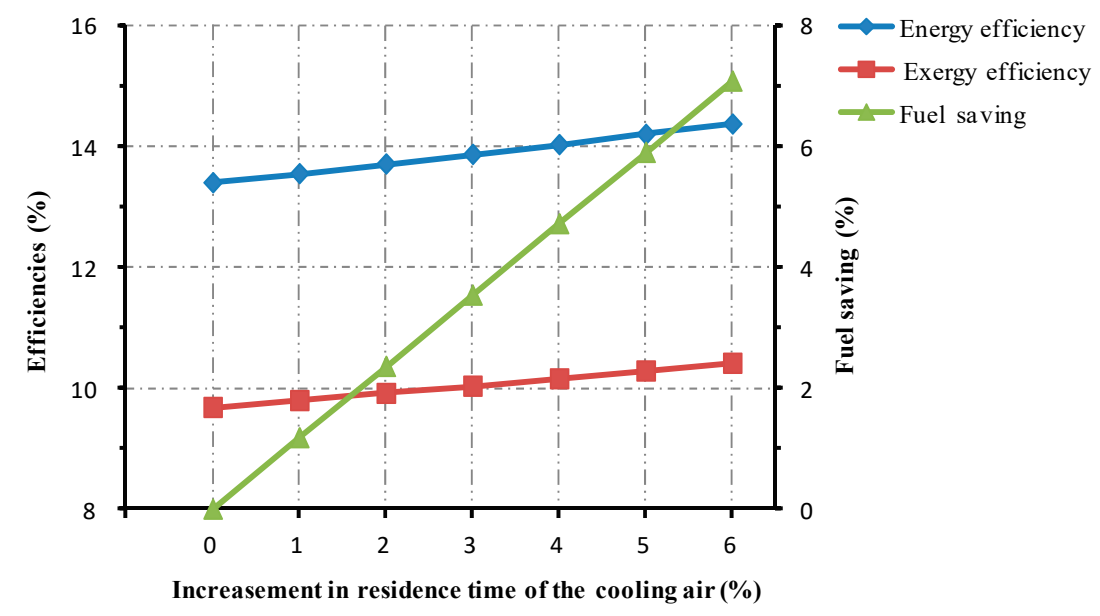

Figure 10. Impacts on energy and exergy efficiencies and fuel-saving of the roller kiln with changes in the residence time of the cooling air.

It is noted that the prolongation of cooling air residence time also affects the production time of other processes, such as the calcining process, as these processes are continuous. Therefore, it leads to a drop in the production of tile per unit time. With every $1 \%$ increase in residence time of the cooling air, the studied kiln experiences an approximately $1.13 \%$ drop in tile production. Increasing the residence time of cooling air improves the thermal efficiency of the roller kiln, but at the expense of tile production.

\subsection{Cost and Environmental Analysis}

The cost-saving and environmental emission reduction can be evaluated according to Equations (11) and (12). The results for different operating parameters are shown in Table 12. For the cost analysis, it has been found that the cooling air residence time has the highest cost-saving of $7.590 \mathrm{RMB} / \mathrm{h}$; corresponding to $50.25 \%$ of the total cost-saving. By changing the cooling air mass and cooling air temperature, the cost-savings have been assessed at $2.836 \mathrm{RMB} / \mathrm{h}$ and $4.679 \mathrm{RMB} / \mathrm{h}$, respectively. In the environmental analysis, the present study mainly considers carbon dioxide emission, which could be the potential for global warming. As depicted, similar results could be acquired from the environmental perspective. The average carbon dioxide emission reduction with the best performance can be achieved by variation of cooling air residence time, followed by the cooling air mass and cooling air temperature. The corresponding emission reduction values are $28.363 \mathrm{~kg} / \mathrm{h}, 17.484 \mathrm{~kg} / \mathrm{h}$ and $10.597 \mathrm{~kg} / \mathrm{h}$.

Table 12. Cost analysis and environmental analysis for different operating parameters.

\begin{tabular}{ccccc}
\hline & \multicolumn{2}{c}{ Cost Analysis } & \multicolumn{2}{c}{ Environmental Analysis } \\
\cline { 2 - 5 } Operating Parameters & $\begin{array}{c}\text { Average } \\
\text { Cost-saving } \\
\mathbf{( R M B / h )}\end{array}$ & $\begin{array}{c}\text { Contribution } \\
\mathbf{( \% )}\end{array}$ & $\begin{array}{c}\text { Average Carbon } \\
\text { Dioxide Emission } \\
\text { Reduction } \mathbf{( k g / h )}\end{array}$ & $\begin{array}{c}\text { Contribution } \\
\mathbf{( \% )}\end{array}$ \\
\hline $\begin{array}{c}\text { Cooling air mass } \\
\text { Cooling air temperature }\end{array}$ & 2.836 & 18.774 & 10.597 & $18.774 \%$ \\
Cooling air residence & 4.679 & 30.976 & 17.484 & $30.976 \%$ \\
time & 7.590 & 50.250 & 28.363 & $50.250 \%$ \\
Total & 15.104 & 100.000 & 56.444 & 100.000 \\
\hline
\end{tabular}




\section{Conclusions}

According to the first and second laws of thermodynamics, this paper presents a comprehensive energy and exergy analysis for the roller kiln and discusses the influence of the parameters of the cooling system on thermal performance, fuel-saving, cost-saving and environmental impact for the roller kiln. The main conclusions are summarized as follows:

1. The targeted physical-chemical reactions only account for $13.4 \%$ of the total energy input, while the exergy value is $9.7 \%$. These results indicate that the system has a very poor thermal performance.

2. The main sources of exergy destruction generated from the heat and mass transfer and fuel combustion are about $14,615,289 \mathrm{~kJ} / \mathrm{h}$, accounting for $75.4 \%$ of the exergy input $-50.8 \%$ of the exergy destruction is due to the heat and mass transfer, while $37.9 \%$ of the exergy destruction is caused by fuel combustion. The results also show that the heating system is the subsystem with greater exergy destruction.

3. Changing operational parameters in the cooling system could affect the thermal performance of the roller kiln. For every $1 \%$ increase in cooling air mass flow, the energy and the exergy efficiencies of the kiln increase roughly by $0.06 \%$ and $0.04 \%$. Increasing the temperature of the cooling gas by $1 \%$, the energy efficiency experiences an approximate drop of $0.09 \%$, while the associated exergy efficiency drops by $0.07 \%$. Prolonging the residence time of the cooling gas by $1 \%$, the studied kiln experiences approximately $0.16 \%$ and $0.12 \%$ rises in energy and exergy efficiencies, respectively.

4. The cooling air residence time has the main impact on the cost-saving and carbon dioxide emission reduction, followed by cooling air mass and cooling air temperature.

Author Contributions: Main idea, Y.W.; formal analysis, Y.W. and H.Y.; writing-original draft preparation, Y.W.; writing-review and editing, Y.W., H.Y. and K.X.; Project Administration, H.Y.; Supervision, Y.W., H.Y. and K.X. All authors have read and agreed to the published version of the manuscript.

Funding: This research was funded by the National Natural Science Foundation of China (Grant No: U1501248, 51905109).

Conflicts of Interest: The authors declare no conflicts of interest.

\section{Nomenclatures}

\section{Nomenclature}

A

$\mathrm{C}_{\mathrm{P}}$

CS

ex

En

Ėn

Ex

Ex

EC

EER

ES

FE

FC

$\mathrm{H}$

LHV

$\mathrm{m}$

$\dot{\mathrm{m}}$

$\mathrm{P}$

q

Q

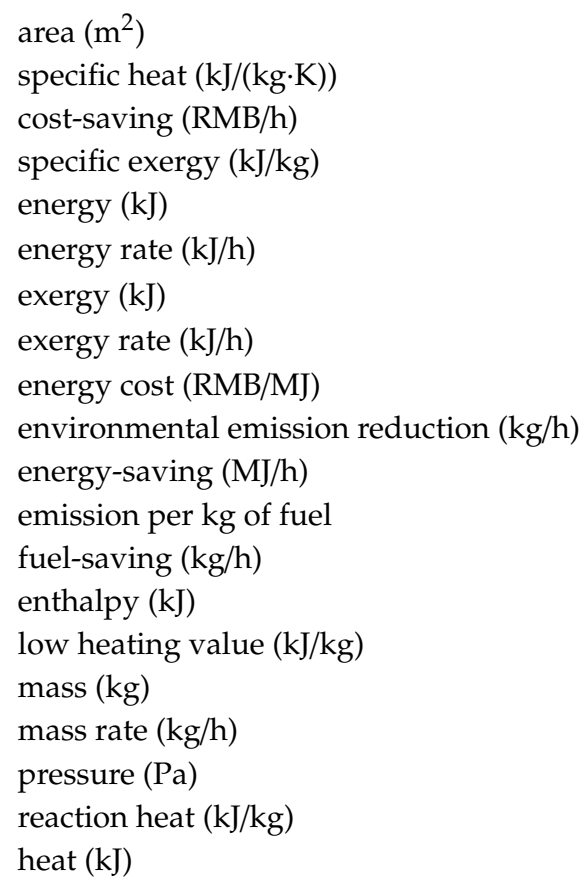




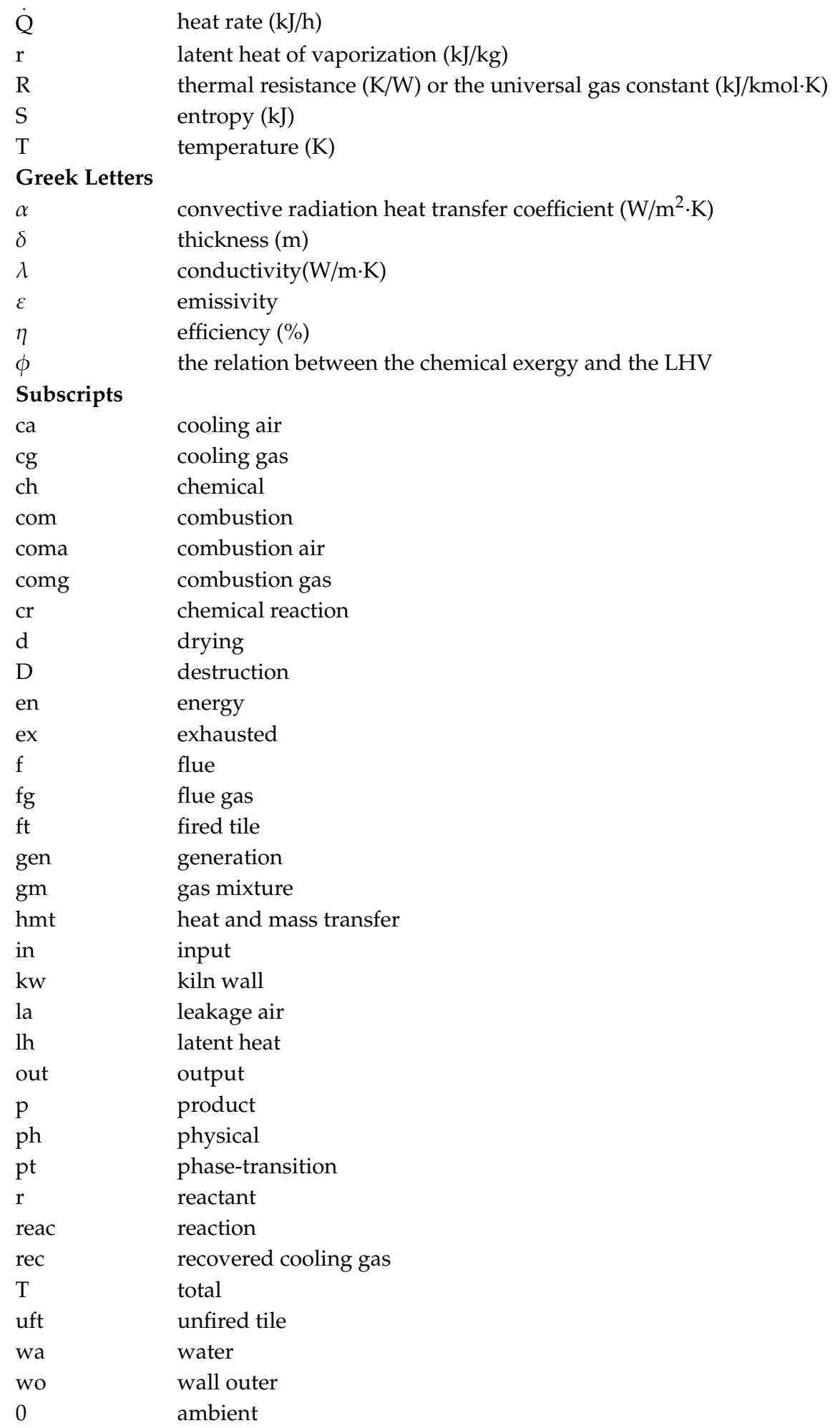

\section{References}

1. Montfort, E.; Mezquita, A.; Granel, R.; Vaquer, E.; Escrig, A.; Miralles, A.; Zaera, V. Analysis of energy consumption and carbon dioxide emissions in ceramic tile manufacture. Bol. Soc. Esp. Ceram. Vidr. 2010, 49, 303-310.

2. Milani, M.; Montorsi, L.; Stefani, M.; Saponelli, R.; Lizzano, M. Numerical analysis of an entire ceramic kiln under actual operating conditions for the energy efficiency improvement. J. Environ. Manag. 2017, 203, 1026-1037. [CrossRef] 
3. Delpech, B.; Milani, M.; Montorsi, L.; Boscardin, D.; Chauhan, A.; Almahmoud, S.; Axcell, B.; Jouhara, H. Energy efficiency enhancement and waste heat recovery in industrial processes by means of the heat pipe technology: Case of the ceramic industry. Energy 2018, 158, 656-665. [CrossRef]

4. Caglayan, H.; Caliskan, H. Investigation of the energy recovery in the burners of the ceramic factory kiln. Energy Procedia 2018, 144, 118-124. [CrossRef]

5. Mezquita, A.; Boix, A.; Monfort, E.; Mallol, G. Energy saving in ceramic tile kilns: Cooling gas heat recovery. Appl. Therm. Eng. 2014, 65, 102-110. [CrossRef]

6. BoroumandJazi, G.; Rismanchi, B.; Saidur, R. A review on exergy analysis of industrial sector. Renew. Sustain. Energy Rev. 2013, 27, 198-203. [CrossRef]

7. Koroneos, C.; Roumbas, G.; Moussiopoulos, N. Exergy analysis of cement production. Int. J. Exergy 2005, 2, 55-68. [CrossRef]

8. Utlu, Z.; Sogut, Z.; Hepbasli, A.; Oktay, Z. Energy and exergy analyses of a raw mill in cement production. Appl. Therm. Eng. 2006, 26, 2479-2489. [CrossRef]

9. Amiri Rad, E.; Mohammadi, S. Energetic and exergetic optimized Rankine cycle for waste heat recovery in a cement factory. Appl. Therm. Eng. 2018, 132, 410-422. [CrossRef]

10. Sögüt, M.Z. A research on exergy consumption and potential of total $\mathrm{CO}_{2}$ emission in the Turkish cement sector. Energy Convers. Manag. 2012, 56, 37-45. [CrossRef]

11. Karellas, S.; Leontaritis, A.D.; Panousis, G.; Bellos, E.; Kakaras, E. Energetic and exergetic analysis of waste heat recovery systems in the cement industry. Energy 2013, 58, 147-156. [CrossRef]

12. Renó, M.L.G.; Torres, F.M.; da Silva, R.J.; Santos, J.J.C.S.; Melo, M.L.N.M. Exergy analyses in cement production applying waste fuel and mineralizer. Energy Convers. Manag. 2013, 75, 98-104. [CrossRef]

13. Ustaoglu, A.; Alptekin, M.; Akay, M.E. Thermal and exergetic approach to wet type rotary kiln process and evaluation of waste heat powered ORC (Organic Rankine Cycle). Appl. Therm. Eng. 2017, 112, 281-295. [CrossRef]

14. Camdali, U.; Tunc, M.; Dikec, F. A thermodynamic analysis of a steel production step carried out in the ladle furnace. Appl. Therm. Eng. 2001, 21, 643-655. [CrossRef]

15. Mert, M.S.; Dilmaç, O.F.; Özkan, S.; Karaca, F.; Bolat, E. Exergoeconomic analysis of a cogeneration plant in an iron and steel factory. Energy 2012, 46, 78-84. [CrossRef]

16. Wu, J.; Wang, R.; Pu, G.; Qi, H. Integrated assessment of exergy, energy and carbon dioxide emissions in an iron and steel industrial network. Appl. Energy 2016, 183, 430-444. [CrossRef]

17. Rong, W.; Li, B.; Liu, P.; Qi, F. Exergy assessment of a rotary kiln-electric furnace smelting of ferronickel alloy. Energy 2017, 138, 942-953. [CrossRef]

18. Rong, W.; Li, B.; Qi, F.; Cheung, S.C.P. Energy and exergy analysis of an annular shaft kiln with opposite burners. Appl. Therm. Eng. 2017, 119, 629-638. [CrossRef]

19. Gutiérrez, A.S.; Martínez, J.B.C.; Vandecasteele, C. Energy and exergy assessments of a lime shaft kiln. Appl. Therm. Eng. 2013, 51, 273-280. [CrossRef]

20. Gürtürk, M.; Oztop, H.F. Energy and exergy analysis of a rotary kiln used for plaster production. Appl. Therm. Eng. 2014, 67, 554-565. [CrossRef]

21. Gürtürk, M.; Oztop, H.F. Exergoeconomic analysis of a rotary kiln used for plaster production as building materials. Appl. Therm. Eng. 2016, 104, 486-496. [CrossRef]

22. Karamarkovic, V.; Marasevic, M.; Karamarkovic, R.; Karamarkovic, M. Recuperator for waste heat recovery from rotary kilns. Appl. Therm. Eng. 2013, 54, 470-480. [CrossRef]

23. Utlu, Z.; Hepbasl, A. Exergoeconomic analysis of energy utilization of drying process in a ceramic production. Appl. Therm. Eng. 2014, 70, 748-762. [CrossRef]

24. Kandilli, C.; Ayna, O.M.; Sahin, M. Evaluation of the performance of a hydrogen enriched combustion system for ceramic sector. Int. J. Hydrog. Energy 2015, 40, 11195-11206. [CrossRef]

25. Caglayan, H.; Caliskan, H. Energy, exergy and sustainability assessments of a cogeneration system for ceramic industry. Appl. Therm. Eng. 2018, 136, 504-515. [CrossRef]

26. Ferrer, S.; Mezquita, A.; Aguilella, V.M.; Monfort, E. Beyond the energy balance: Exergy analysis of an industrial roller kiln firing porcelain tile. Appl. Therm. Eng. 2019, 150, 1002-1015. [CrossRef]

27. Çengel, Y.A.; Boles, M.A. Thermodynamics: An Engineering Approach, 5th ed.; McGraw-Hill: New York, NY, USA, 2006. 
28. Atmaca, A.; Yumrutas, R. Analysis of the parameters affecting energy consumption of a rotary kiln in cement industry. Appl. Therm. Eng. 2014, 66, 435-444. [CrossRef]

29. Hu, G.L. Build Ceramic Industrial Roller Kiln; Light Industry Press: Beijing, China, 1998. (In Chinese)

30. Kotas, T.J. The Exergy Method of Thermal Plant Analysis; Anchor Brendon Ltd.: London, UK, 1985.

31. Kotas, T.J. The Exergy Method of Thermal Plant Analysis; Krieger Publishing: Malabar, FL, USA, 1995.

32. Wajs, J.; Golabek, A.; Bochniak, R.; Mikielewicz, D. Air-cooled photovoltaic roof tile as an example of the BIPVT system An experimental study on the energy and exergy performance. Energy 2020, 197, 117-255. [CrossRef]

33. Shoeibi, S.; Rahbar, N.; Esfahlani, A.A.; Kargarsharifabad, H. Application of simultaneous thermoelectric cooling and heating to improve the performance of a solar still: An experimental study and exergy analysis. Appl. Energy 2020, 263, 114581. [CrossRef]

34. Yu, L.D.; Chen, Q.B. Thermal Balance Calculation of Ceramic Equipment; Light Industry Press: Beijing, China, 1990. (in Chinese)

35. Barin, I. Thermalchemical Data of Pure Substances; Wiley-VCH: Weinheim, Germany, 1997.

36. Lin, C.X.; Bai, Z.H.; Zhang, Z.R. Thermodynamic Data Manual for Minerals and the Related Compounds; Science Press: Beijing, China, 1985. (in Chinese)

37. Luis, P.; Van der Bruggen, B. Exergy analysis of energy-intensive production processes: Advancing towards a sustainable chemical industry. J. Chem. Technol. Biotechnol. 2014, 89, 1288-1303. [CrossRef]

(C) 2020 by the authors. Licensee MDPI, Basel, Switzerland. This article is an open access article distributed under the terms and conditions of the Creative Commons Attribution (CC BY) license (http://creativecommons.org/licenses/by/4.0/). 